\title{
BIOLOGICAL INFLUENCES ON SEAFLOOR CARBONATE PRECIPITATION
}

Author(s): KRISTIN D. BERGMANN , JOHN P. GROTZINGER and WOODWARD W. FISCHER Source: PALAIOS, 28(2):99-115. 2013.

Published By: Society for Sedimentary Geology

URL: http://www.bioone.org/doi/full/10.2110/palo.2012.p12-088r

BioOne (www.bioone.org) is a nonprofit, online aggregation of core research in the biological, ecological, and environmental sciences. BioOne provides a sustainable online platform for over 170 journals and books published by nonprofit societies, associations, museums, institutions, and presses.

Your use of this PDF, the BioOne Web site, and all posted and associated content indicates your acceptance of BioOne's Terms of Use, available at www.bioone.org/page/terms_of_use.

Usage of BioOne content is strictly limited to personal, educational, and non-commercial use. Commercial inquiries or rights and permissions requests should be directed to the individual publisher as copyright holder. 


\title{
BIOLOGICAL INFLUENCES ON SEAFLOOR CARBONATE PRECIPITATION
}

\author{
KRISTIN D. BERGMANN,* JOHN P. GROTZINGER, and WOODWARD W. FISCHER \\ Division of Geological and Planetary Sciences, California Institute of Technology, 1200 East California Boulevard, Pasadena, California 91125, USA, \\ bergmann@caltech.edu,grotz@gps.caltech.edu,wfischer@caltech.edu
}

\begin{abstract}
The sedimentary record reveals first-order changes in the locus of carbonate precipitation through time, documented in the decreasing abundance of carbonate precipitation on the seafloor. This pattern is most clearly recorded by the occurrence of seafloor carbonate crystal fans (bladed aragonite pseudomorphs neomorphosed to calcite or dolomite), which have a distinct temporal distribution, ubiquitous in Archean carbonate platforms, but declining through Proterozoic time and extremely rare in Phanerozoic basins. To understand better the potential influences on this pattern, we built a mathematical framework detailing the effects of organic matter delivery and microbial respiratory metabolisms on the carbonate chemistry of shallow sediments. Two nonunique end-member solutions emerge in which seafloor precipitation is favorable: enhanced anaerobic respiration of organic matter, and low organic matter delivery to the sediment-water interface. This analysis suggests that not all crystal fans reflect a unique set of circumstances; rather there may have been several different geobiological and sedimentary mechanisms that led to their deposition. We then applied this logical framework to better understand the petrogenesis of two distinct crystal fan occurrences-the Paleoproterozoic Beechey Formation, Northwest Territories, Canada, and the middle Ediacaran Rainstorm Member of the Johnnie Formation, Basin and Range, United States-using a combination of high-resolution petrography, micro X-ray fluorescence and wavelength dispersive spectroscopy, $\mathrm{C}$ isotopes, and sedimentary context to provide information on geobiological processes occurring at the sediment-water interface. Interestingly, both of these Proterozoic examples are associated with iron-rich secondary mineral assemblages, have elevated trace metal signatures, and sit within maximum flooding intervals, highlighting key commonalities in synsedimentary geobiological processes that led to seafloor carbonate precipitation.
\end{abstract}

\section{INTRODUCTION}

The sedimentary record demonstrates that large-scale aspects of carbonate deposition have remained unchanged over $>3.4 \mathrm{Ga}$ of Earth history (Grotzinger and James, 2000). This reflects long-term commonalities in the sources and sinks of dissolved inorganic carbon (DIC) and alkalinity in seawater and the processes that generate and fill accommodation in sedimentary basins. Despite this stability, the record also reveals important first-order changes, at smaller length scales, in the nature of carbonate precipitation through time; this is documented in the decreasing abundance of seafloor carbonate precipitation (Table 1, references therein). Changes in carbonate precipitation dynamics are also evidenced in Precambrian precipitated stromatolite morphologies, herringbone calcite, molar tooth structure, and giant ooids (Grotzinger, 1989; Sumner and Grotzinger, 1993, 1996a; Grotzinger and Knoll, 1999; Grotzinger and James, 2000). The reemergence of seafloor-precipitated crystal fans in subtidal carbonate environments after Paleoproterozoic time is important because each

\footnotetext{
* Corresponding author.

Published Online: February 2013
}

Copyright $\odot$ 2013, SEPM (Society for Sedimentary Geology) example coincides with known carbon cycle perturbations (Grotzinger and Knoll, 1995; Knoll et al., 1996; Hoffman and Schrag, 2002). Uncovering the basis for these occurrences holds an important key to understanding secular changes in the linkages between acid-base and redox processes on the surface Earth (Grotzinger and Knoll, 1995; Grotzinger and James, 2000; Higgins et al., 2009).

Herein, we explore the potential importance of sediment-water interface chemistry and the impact of microbial respiration on the temporal distribution of seafloor crystal fans through time. We begin with methods and results from a mathematical model exploring the effects of organic matter delivery and different respiratory metabolisms on the carbonate chemistry of the sediment-water interface. This framework makes specific predictions for the signature of biologically influenced precipitation that we then test with a variety of sedimentologic, petrographic, and isotopic observations. We focused on two Proterozoic crystal fan-containing deposits widely distributed in timethe upper Paleoproterozoic Beechey Formation, Northwest Territories, Canada, and the middle Ediacaran Rainstorm Member of the Johnnie Formation, Basin and Range, United States. We show observations from a range of high-resolution petrographic techniques that provide insight into the sedimentary geochemistry of the environments in which they grew.

\section{Occurrences of Aragonite Seafloor Crystal Fans in the Sedimentary Record}

Subtidal aragonite seafloor-precipitated crystal fans were first described from the Paleoproterozoic Odjick-Rocknest transition, Canada (Grotzinger and Read, 1983). Since then, many occurrences of seafloor aragonite pseudomorphs have been documented in carbonate successions. These occurrences were compiled in Grotzinger (1989) and in Grotzinger and James (2000). An updated tabulation is shown in Table 1. A crucial outcome of the existing body of work is the distinct temporal distribution of carbonate crystal fans. They are ubiquitous in Archean carbonate platforms, common in upper Paleoproterozoic carbonate platforms, and are restricted to peritidal environments during Mesoproterozoic time (Grotzinger, 1989; Grotzinger and James, 2000). There are noticeable gaps in the crystal fan record between $3.5 \mathrm{Ga}$ and $3 \mathrm{Ga}$, between $2.5 \mathrm{Ga}$ and $2 \mathrm{Ga}$, and between $\sim 580 \mathrm{Ma}$ and the present, except for Permian and Early Triassic occurrences (Table 1). During Precambrian time, wherein the record of preserved carbonates is scarcer and the age constraints are fewer, the temporal distribution likely reflects both a true change in carbonate depositional style as well as a strong bias associated with the preserved rock record. In general, the record gets poorer with age, and yet even with a diminished record, crystal fans are an important component of the few preserved Archean carbonate platforms (e.g., Sumner and Grotzinger, 2000; Allwood et al., 2009). Here the signal clearly stands out from the bias. That in mind, the scarcity of carbonate platforms of middle Archean and early Paleoproterozoic age highlights the likelihood that both the $3.5 \mathrm{Ga}$ to $3 \mathrm{Ga}$ gap and $2.5 \mathrm{Ga}$ and $2 \mathrm{Ga}$ gap may be directly due to record bias. As summarized previously (Grotzinger, 1989; Grotzinger and James, 2000), subtidal crystal fans 
TABLE 1-Ages, geological names, references, and significant context of documented crystal fan occurrences from the sedimentary record.

\begin{tabular}{|c|c|}
\hline Best age $(\mathrm{Ma})$ & Location and reference \\
\hline 3,450 & $\begin{array}{l}\text { Strelley Pool Formation, Waarrawoona Greenstone Belt, } \\
\text { Western Australia (Grotzinger, 1989; Allwood et al., 2009) }\end{array}$ \\
\hline 2,940 & Uchi Greenstone Belt, Canada (Sumner and Grotzinger, 2000) \\
\hline 2,700 & $\begin{array}{l}\text { Cheshire Formation, Belingwe Greenstone Belt, Zimbabwe } \\
\text { (Grotzinger, 1989; Sumner and Grotzinger, 2000; Hofmann } \\
\text { et al., 2004), Steep Rock Group, Canada (Grotzinger, 1989; } \\
\text { Kusky and Hudleston, 1999; Sumner and Grotzinger, 2000) }\end{array}$ \\
\hline 2,600 & $\begin{array}{l}\text { Hunstman Formation, Zimbabwe (Sumner and Grotzinger, 2000; } \\
\text { Hofmann et al., 2004), Carawine Formation, Australia } \\
\text { (Sumner and Grotzinger, 2000) }\end{array}$ \\
\hline 2,540 & $\begin{array}{l}\text { Campbellrand-Malmani Platform, South Africa (Sumner and } \\
\text { Grotzinger, 2000; Sumner and Grotzinger, 2004) }\end{array}$ \\
\hline 2,500 & Yellowknife Supergroup, Canada (Grotzinger, 1989) \\
\hline 1,970 & $\begin{array}{l}\text { Beechey Formation, Canada (Grotzinger and Friedman, 1989; } \\
\text { Grotzinger, 1993) }\end{array}$ \\
\hline 1,900 & Odjick-Rocknest Boundary, Canada (Grotzinger and Read, 1983), \\
\hline 1,880 & Pethei Group, Canada (Sami and James, 1996) \\
\hline 1,640 & Teena Formation, McArthur Group, Australia (Winefield, 2000) \\
\hline 1,400 & $\begin{array}{l}\text { Gaoyuzhuang Formation, China (Seong-Joo and Golubic, 2000), } \\
\text { Kotuikan Formation, Siberia (Bartley et al., 2000) }\end{array}$ \\
\hline 1,200 & Ruyang Group, China (Xiao et al., 1997) \\
\hline 1,100 & Society Cliffs Formation, Canada (Kah and Knoll, 1996) \\
\hline 740 & Bambui Group, Brazil (Peryt et al., 1990; Babinski et al., 2007) \\
\hline $667 ?$ & $\begin{array}{l}\text { Pocatello Formation, United States (Corsetti et al., 2004; } \\
\text { Lorentz et al., 2004) }\end{array}$ \\
\hline 630 & $\begin{array}{l}\text { Maieberg Formation, Namibia (Hoffman et al., 1998; Hoffman et al., } \\
\text { 2007), Mt. Doreen Formation, Australia (Kennedy, 1996), } \\
\text { Bushmansklippe Formation, Namibia (Saylor et al., 1998), } \\
\text { Hayhook Formation, Canada (James et al., 2001), Mirasol d'Oeste } \\
\text { Formation, Brazil (Font et al., 2006), Ol Member, Tsagaan Oloom } \\
\text { Formation (Macdonald et al., 2009a), Katakuruk Formation, } \\
\text { Alaska (Clough and Goldhammer, 2000; Macdonald et al., 2009b) }\end{array}$ \\
\hline 580 & Johnnie Formation, United States (Summa, 1993; Pruss et al., 2008) \\
\hline 265 & Capitan Reef, United States (Grotzinger and Knoll, 1995) \\
\hline 252 & $\begin{array}{l}\text { Shareza Formation, Iran (Baud et al., 2007), Abedah, Turkey } \\
\text { (Heydari and Hassanzadeh, 2003; Heydari et al., 2003), } \\
\text { Kokarkuyu Formation, Turkey (Pruss et al., 2006), Guizhou, } \\
\text { China (Payne et al., 2007), Cekic Dagi Formation, Turkey } \\
\text { (Payne et al., 2007), Mitai and Kamura Formations, Japan } \\
\text { (Payne et al., 2007), }\end{array}$ \\
\hline 251 & Alwa Formation, Oman (Woods and Baud, 2008) \\
\hline
\end{tabular}

Context

Flat pebble conglomerates assoc. with crystal fans

Cheshire Fm.-Crystal fans grow from erosional surfaces and lag deposits of detrital sediments, intimately associated with microbial laminae. Steep Rock Group - within fenestral microbial laminae

Huntsman Fm. - crystal fans are interbedded with interpreted microbial laminae and black coatings

Carawine Fm.- draped in sediments and sometimes reworked

Found in subtidal through supratidal depositional environments

Crystal fans associated with granular iron formation, sit on transgressive surface

Thin authigenic hematite coatings on crystal fans, sit on transgressive surface

Crystal fans interbedded with pink carbonates and sit at the transgressive surface

Gaoyuzhuang Fm. - crystal fans associated with sediment rich layers and are red-brown in color. Both crystal fan occurrences are peritidal.

Crystal fans draped by darker, micritic laminae, blades highlighted by organic matter or hematite

Peritidal crystal fans associated with evaporites

High Sr concentrations, Crystal fans are grey in color and are associated with red lime mudstones

Crystal fans are associated with pink limestones and are draped with micritic or siliclastic sediments.

Crystal fans sit at the dolomite-limestone transition associated with the maximum flooding interval following the Marinoan Glaciation. They are often associated with pink limestones, authigenic minerals and microbial laminae. Detrital hematite is noted in the Maieberg Formation.

Sit at the maximum flooding interval in pink limestones, dense detrital grains particularly hematite are associated with the crystal fans and nucleation surface Reef cavity botryoids, no known examples of direct precipitation on the seafloor

In the Shareza and Kokarkuyu Fms., the crystal fans are forming on flooded or drowning platforms.

Iron-manganese coatings described within sequence that contains crystal fans

reminiscent of Archean and upper Paleoproterozoic seafloor crystal fans reappear in Neoproterozoic and Phanerozoic successions during periods of perturbation to the ocean-atmosphere system - most notably directly overlying the cap carbonate dolostones associated with the Marinoan glaciation (Hegenberger, 1993; Saylor et al., 1998; Clough and Goldhammer, 2000; James et al., 2001; Font et al., 2006; Hoffman et al., 2007; Macdonald et al., 2009a, 2009b) and around the Permian-Triassic mass extinction (Grotzinger and Knoll, 1995; Heydari et al., 2003; Pruss et al., 2006; Baud et al., 2007; Payne et al., 2007). The sedimentary record of the past 630 million years is, in many ways, much clearer and far more continuous, yet during this interval seafloor-precipitated fabrics are not ever a common component of carbonate platforms.

The striking nature of this long-term temporal pattern has generated a variety of explanations (Sumner and Grotzinger, 1996b; Grotzinger and James, 2000; Higgins et al., 2009). Broadly, the distribution of $\mathrm{CaCO}_{3}$ precipitation and dissolution within the ocean is dependent on the size of the DIC reservoir, the pressure- and temperature-dependent solubility of carbonate minerals, and the strength and metabolisms of organic carbon production and respiration. In modern ocean basins, large gradients in carbonate saturation state between surface and deep seawater exist because of a strong biological pump, high $\mathrm{pO}_{2}$, and aerobic respiration of organic carbon (Higgins et al., 2009; Knoll and Fischer, 2011). A longstanding interpretation of the temporal distribution of crystal fan occurrences has involved a decrease in surface seawater carbonate saturation state through time (Grotzinger 1990; Sumner and Grotzinger, 1996b; Grotzinger and James, 2000). Under this hypothesis, Archean oceans were characterized by highly supersaturated surface seawater and crystal fans would have formed during rapid precipitation events. Higgins et al. (2009) proposed that periods of abundant in situ seafloor precipitation were characterized by a small gradient in carbonate saturation from the surface to the deep ocean, controlled by widespread anaerobic respiration of organic carbon and a large DIC reservoir and/or a weak biological pump. In this framework, the temporal decline of seafloor-precipitated textures preserved in Precambrian carbonate platforms can be explained as a product of increasing $\mathrm{pO}_{2}$ and aerobic respiration of organic carbon as well as decreasing $\mathrm{pCO}_{2}$ and a shrinking DIC reservoir (Grotzinger and Kasting, 1993; Higgins et al., 2009).

One key to understanding the nature of seafloor carbonate fans is recognition that these features were influenced by and record mass 
fluxes across the sediment-water interface. Despite strongly supersaturated seawater with respect to both aragonite and calcite over modern carbonate platforms, this style of seafloor precipitation does not occur today. Today, dissolution in shallow sediments near the sediment-water interface is driven by the aerobic respiration of organic matter (and oxidation of other sedimentary reductants like sulfide), which increases aqueous $\mathrm{CO}_{2}$, consumes alkalinity, and lowers $\mathrm{pH}$ (Walter and Burton, 1990; Walter et al., 1993; Hu and Burdige, 2007, 2008). This highlights the importance of local gradients in carbonate saturation state; these gradients are due in large part to the effects of biology, and have changed over the course of Earth history.

\section{CARBONATE CHEMISTRY AT THE SEDIMENT-WATER INTERFACE}

Supersaturated surface waters overlying modern carbonate platforms should drive carbonate seafloor precipitation based on thermodynamic predictions $(\Omega>1)$, and many studies have shown that supersaturated seawater does indeed result in the inorganic precipitation of carbonate minerals. The location of these precipitates in the modern ocean, however, is telling (Broecker and Takahashi, 1966; Ginsburg and James, 1976; Grammer et al., 1993, 1999; Broecker et al., 2001). Aragonite precipitates have been documented within reef cavities as large botryoidal fans and as fine needles precipitated on carbonate grains suspended in the water column at 30 and $60 \mathrm{~m}$ depth (Ginsburg and James, 1976; Grammer et al., 1999). Inorganic precipitation also occurs from seawater onto preexisting aragonite needles during whitings events (Broecker and Takahashi, 1966; Broecker et al., 2001; Morse et al., 2003). Other types of carbonate precipitates exist within modern carbonate supersaturated environments but these sit more clearly within a continuum of biologically mediated and abiotic precipitates; these include ooids and various cements including hardground, beachrock, and stromatolite cements (Reid et al., 2000; Andres et al., 2006; Morse et al., 2007; Dupraz et al., 2009).

If tropical surface seawater $\left(\Omega_{\text {aragonite }} \sim 3\right)$ can produce aragonite precipitates, the question of why these features do not form on the seafloor in the modern becomes an important juxtaposition against the occurrences of seafloor precipitates in the rock record. Seawater is not uniform with regard to its carbonate chemistry, and processes occurring in shallow sediments and at the sediment-water interface play an important role in the probability of crystal fan nucleation and growth. The dominant controls on whether precipitation is viable at the sediment-water interface include the acid-base and redox chemistry occurring on the seafloor and in shallow sediments, the balance between the kinetics of carbonate precipitation rate and background sedimentation rate, and physical processes like bioturbation that drive mixing and perturb mass flux across the sediment-water interface.

Studies of carbonate platform environments reveal evidence for carbonate dissolution in near-surface sediments though a complex set of processes (Walter and Burton, 1990; Walter et al., 1993; Ku et al., 1999; Hu and Burdige, 2007, 2008). Both aerobic respiration and sulfate reduction decrease the $\mathrm{pH}$ in sediment pore waters undergoing organic diagenesis (Canfield, 1989; Walter and Burton, 1990). On carbonate platforms, pore water profiles indicate that sulfate reduction begins within $5 \mathrm{~cm}$ of the sediment-water interface in many environments (Walter and Burton, 1990; $\mathrm{Hu}$ and Burdige, 2007). Furthermore, with limited iron concentrations in shallow carbonate environments, the hydrogen sulfide produced during sulfate reduction diffuses upward and is reoxidized (commonly by $\mathrm{O}_{2}$ ) in shallower sediments or at the sediment-water interface, often associated with bioturbation (Walter et al., 1993; Ku et al., 1999). The oxidation of the hydrogen sulfide produces the bulk of the acidity contributing to the dissolution of carbonate phases with smaller contributions from aerobic respiration and sulfate reduction (Walter et al., 1993). The accumulation of $\mathrm{Ca}^{2+}$ and $\mathrm{CO}_{3}{ }^{2-}$ ions in the pore fluids driven by microbial respiration and carbonate dissolution can result in carbonate precipitation (and cementation) at greater depths in the sediments but not commonly near the sediment-water interface (Hu and Burdige, 2007). Thus, the combined effect of the two dominant microbial respiration pathways (in modern ocean basins) and the twofold effects of bioturbation - both physical disruption of the sediment-water interface and promoting hydrogen sulfide oxidation - serve as important chemical and physical hindrances to seafloor-precipitated crystal fans on modern carbonate platforms. Ultimately these studies reveal that geobiological processes that include the synthesis and respiration of organic carbon, contributions to alkalinity from anaerobic metabolisms, and bioturbation fundamentally control the carbonate chemistry of the environments in which crystal fans would nucleate and grow and form the foundation for our model of the sediment-water interface.

\section{Modeling methods}

We constructed an explicit framework to evaluate the conditions that might hinder or promote the growth of seafloor crystal fans with a focus on the role of geobiological processes in the chemistry of the sediment-water interface. During carbonate precipitation, the growth rate $(\mathrm{R})$ can be related to saturation state $(\Omega)$ through the following rate equation:

$$
R=k\left[\mathrm{CaCO}_{3}\right](\Omega-1)^{n}
$$

where $k$ is the rate constant and $n$ is the rate order and saturation state $(\Omega)$ is defined as:

$$
\Omega=\frac{\left(\gamma \mathrm{Ca}^{2+} \gamma C \mathrm{O}_{3}^{2-}\right)}{K_{s p}}
$$

where $\gamma$ is the activity coefficient and Ksp is the solubility product. As $\Omega$ increases, so does $\mathrm{R}$. The potential mitigating effects of kinetic inhibitors on precipitation rate can be included in the rate equation with the coefficient $k$.

In order to quantify and formalize the possible biological controls on the sediment-water interface chemistry, we used a mathematical model that is designed to explore the carbonate chemistry and saturation state of the sediment-water interface as a thermodynamic statistic to predict the behavior of carbonate precipitation and dissolution. The carbonate chemistry of the sediment-water interface can be understood as the difference between processes occurring in the water column versus those in the shallow sediments that either add or remove DIC and/or alkalinity in their respective environments. We can simulate the effect that the geobiological processes have on the $\mathrm{CaCO}_{3}$ saturation state of the interface with four boxes for dissolved inorganic carbon and alkalinity in the overlying water column $\left(D I C_{w} ; A L K_{w}\right)$ and in the shallow sediments $\left(D I C_{s} ; A L K_{s}\right)$, respectively (Figure 1).

We generate a flux of organic matter-from oxygenic photosynthesis and carbon fixation - to the sediment-water interface and force all remineralization to occur within sediments (Figure 1). We then vary the flux of organic matter and the dominant microbial respiration pathways responsible for organic matter remineralization. These simplifications approximate a variety of marine environments and demonstrate the importance of different microbial respiration pathways on the chemistry at the interface. We overlook precipitation and dissolution feedbacks - which would make true changes in $\Omega$ less than those predicted by the model - with the first-order goal of predicting thermodynamic favorability and likelihood of crystal fan development.

The four differential equations governing the box model are:

$$
\begin{aligned}
& \frac{d D I C_{w}}{d t}=J_{m i x}\left(\left[D I C_{s}\right]-\left[D I C_{w}\right]\right)-J_{\text {org }} \\
& \frac{d D I C_{s}}{d t}=J_{\text {mix }}\left(\left[D I C_{w}\right]-\left[D I C_{s}\right]\right)+J_{\text {org }}
\end{aligned}
$$




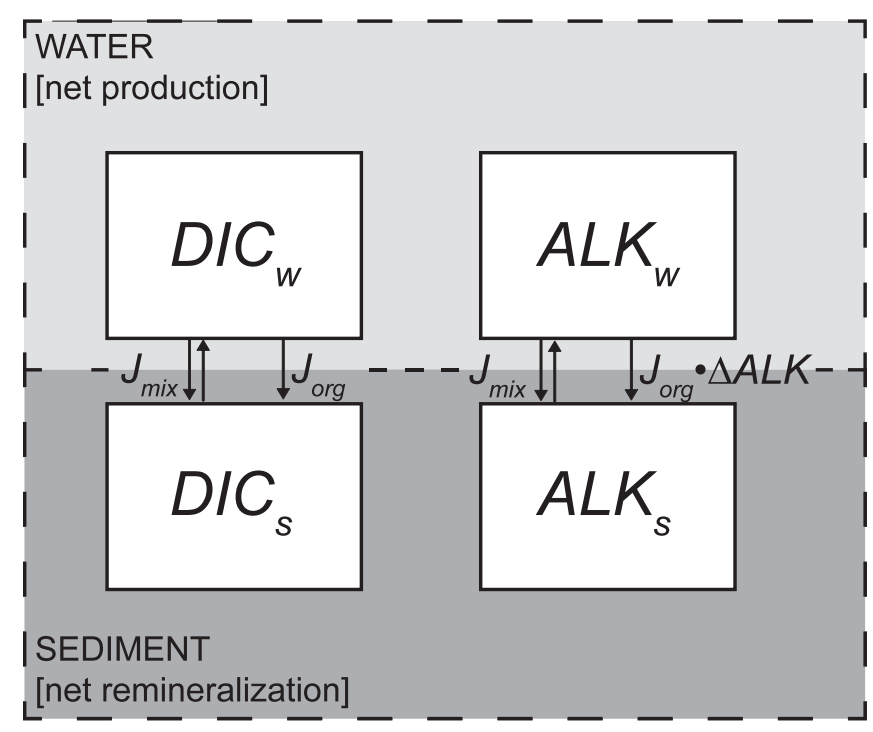

FIGURE 1-Topology of a mathematical model to examine the carbonate chemistry of the sediment-water interface model. DIC = dissolved inorganic carbon; ALK = alkalinity. The $\mathrm{DIC}_{\mathrm{w}}$ and $\mathrm{ALK}_{\mathrm{w}}$ are set to modern seawater values. The chemical work done on the sediment $\mathrm{DIC}_{\mathrm{s}}$ and $\mathrm{ALK}_{\mathrm{s}}$ is a function of the flux of organic material $\left(=\mathrm{J}_{\mathrm{org}}\right)$ and the alkalinity input from different respiratory metabolisms.

$$
\begin{gathered}
\frac{d A L K_{w}}{d t}=J_{\text {mix }}\left(\left[A L K_{s}\right]-\left[A L K_{w}\right]\right)-J_{\text {org }} \Delta A L K \\
\frac{d A L K_{s}}{d t}=J_{\text {mix }}\left(\left[A L K_{w}\right]-\left[A L K_{s}\right]\right)+J_{\text {org }} \Delta A L K
\end{gathered}
$$

where $J_{\text {org }}$ is the flux of organic material to the sediment-water interface and $J_{\text {mix }}$ is the combined effect of advection and diffusion. These two processes would be accounted for differently in a time-dependent model but because we are solving the model at steady state we have simplified their effect into a single term. A steady-state solution implies that removal from the sediment box is in equilibrium with the input. Solving equations 1-4 at steady state and assuming the $J_{m i x}$ term is equal for ALK and DIC yields:

$$
J_{\text {mix }}=\frac{J_{\text {org }}}{\left(\left[D I C_{s}\right]-\left[D I C_{w}\right]\right)}=\frac{J_{\text {org }} \Delta A L K}{\left(\left[A L K_{s}\right]-\left[A L K_{w}\right]\right)}
$$

solving for $A L K_{s}$ yields:

$$
\left[A L K_{s}\right]=\Delta A L K\left(\left[D I C_{s}\right]-\left[D I C_{w}\right]\right)+\left[A L K_{w}\right]
$$

To simulate variable quantities of remineralized organic carbon in the sediment box we used the following expression:

$$
\left[D I C_{s}\right]=\left[D I C_{w}\right]+\left[D I C_{r e \min }\right]
$$

To solve the carbonate chemistry of this system, we adapted a version of the Matlab solver from (Zeebe and Wolf-Gladrow, 2001). Constants were adjusted to those presented in Millero (2007).

For boundary conditions (Table 2) we used values for $\left[D I C_{w}\right]$, $\left[A L K_{w}\right]$ and $\left[\mathrm{Ca}^{2+}\right]$ that reflect modern seawater, but the salient results hold over broad ranges of DIC and alkalinity. While $\left[\mathrm{Ca}^{2+}\right]$ has varied over geologic timescales, it is also likely true that $\left[\mathrm{Ca}^{2+}\right]>\left[\mathrm{CO}_{3}{ }^{2-}\right]$ over most of Earth history and thus gradients in $\Omega$ were dependent on changes in $\left[\mathrm{CO}_{3}{ }^{2-}\right]$ not $\left[\mathrm{Ca}^{2+}\right]$ (Higgins et al., 2009). At extreme end- member solutions of nearly zero $\left[D I C_{w}\right],\left[A L K_{w}\right]$, and $\left[\mathrm{Ca}^{2+}\right]$, model outcomes are strongly affected. The large-scale commonalities in the carbonate producing environments throughout Earth history, however, suggest that these extreme conditions were never met by seawater (Grotzinger and Kasting, 1993; Grotzinger and James, 2000).

\section{Modeling Results}

Modern marine environments demonstrate how inextricably linked the precipitation and dissolution of carbonate minerals are to the processes of organic carbon synthesis and remineralization. The dominant microbial respiration processes occurring in shallow sediments and at the sediment-water interface in the modern, however, have changed throughout Earth history (Higgins et al., 2009; Knoll and Fischer, 2011). This is important, because while respiration always adds DIC, anaerobic respiration pathways also contribute alkalinity, and thus have a different effect on $\Omega$ than aerobic metabolisms (Table 3, Fig. 2). Figure 2 illustrates the alkalinity produced for $10 \mu \mathrm{mol} \mathrm{kg}{ }^{-1}$ of organic matter respired to $\mathrm{CO}_{2}$ for different respiration pathwaysaerobic respiration, sulfate reduction, nitrate reduction, manganese reduction, iron reduction, methanogenesis, and anaerobic oxidation of methane (AOM). The alkalinity contribution was calculated by balancing the stoichiometry of marine organic carbon, oxygen, and hydrogen from Anderson (1995), but ignores the smaller effects of remineralizing nitrogen and phosphorous. In this regard, the alkalinity contributions from these anaerobic metabolisms are further distinct from aerobic respiration. The anaerobic remineralization of nitrogen adds alkalinity because the organic nitrogen is transformed to ammonia but removes alkalinity in oxic settings as organic nitrogen is metabolized, in net, to nitrate (not commonly by the same organisms). Aerobic respiration actually removes a small amount of alkalinity for every mole of $\mathrm{CO}_{2}$ respired because of nitrogen and phosphorous remineralization. Aerobic respiration and methanogenesis are respiration pathways that result in $<1 \mathrm{~mol}$ equivalent alkalinity per mol of $\mathrm{CO}_{2}$ and thus these respiration pathways decrease the carbonate saturation of pore waters (Table 3, Fig. 2). Manganese reduction, iron reduction, the anaerobic oxidation of methane and sulfate reduction promote carbonate precipitation by boosting the carbonate saturation state of pore waters. The relative contribution to alkalinity per mol of $\mathrm{CO}_{2}$ is referred to here as $\triangle \mathrm{ALK}$ and is shown by the slope of the vectors plotted in Figure 2. The resulting effect of these respiration pathways on $\Omega_{\text {aragonite }}$ (contours) is consistent over a broad range of seawater chemistry; however, note that at end-member compositions (either negligible DIC or alkalinity) the effect on $\Omega$ would be different.

The steady-state solutions for this simple two-box model are a function of the flux of organic matter to the sediment-water interface and the effect of different microbial respiration pathways on alkalinity per mol $\mathrm{CO}_{2}(\triangle \mathrm{ALK})$. Results are presented as $\mathrm{pH}$ and $\Omega_{\text {aragonite }}$ of the sediment box (Figs. 3A-B). While each respiratory pathway listed earlier has a specific $\triangle \mathrm{ALK}$ contribution, we explored a continuum in $\triangle \mathrm{ALK}(-1-9)$ to approximate the combined effect of multiple respiratory pathways due to the common limitation of electron acceptors in organic-rich sediments. The dark blue regions represent the sediment box when $\Omega_{\text {aragonite }}$ is less than one (Fig. 3B). These undersaturated environments would promote dissolution of aragonite

\begin{tabular}{|c|c|c|c|c|c|c|c|}
\hline $\mathrm{T}$ & $\mathrm{S}$ & $\mathrm{P}$ & {$\left[\mathrm{Ca}^{2+}\right]$} & $D I C_{w}$ & $A L K_{w}$ & $D I C_{\text {remin }}$ & $\triangle A L K$ \\
\hline $20{ }^{\circ} \mathrm{C}$ & $35 \%$ & $1 \mathrm{~atm}$ & $11 \mathrm{mmol} \mathrm{kg}-1$ & $2100 \mu \mathrm{mol} \mathrm{kg-1}$ & $2300 \mu \mathrm{mol}$ equiv. $\mathrm{kg}^{-1}$ & $0: 5: 500 \mu \mathrm{mol} \mathrm{kg} \mathrm{kg}^{-1}$ & $-1: 0.1: 9$ \\
\hline
\end{tabular}
and are similar to the shallow sediments in the modern ocean.

These calculations demonstrate how the chemistry of the sedimentwater interface can deviate strongly from seawater due to expected

TABLE 2-Boundary conditions for the mathematical model of sediment-water interface carbonate chemistry. 
TABLE 3-Different respiratory metabolisms have unique effects on solution carbonate chemistry. The redox reactions were balanced below using the stoichiometry $\mathrm{C}_{106} \mathrm{H}_{175} \mathrm{O}_{42}$ (Anderson, 1995) to approximate the average redox composition of marine organic matter. The $\triangle \mathrm{ALK}$ term is the change in alkalinity per mol of organic carbon turned to $\mathrm{CO}_{2}$ and was calculated for each reaction as a function of the principal components at the $\mathrm{CO}_{2}$ equivalence point. The $\mathrm{pH}$ column indicates the pH midpoint, below which the reaction will result in a $\mathrm{pH}$ increase and above which the reaction will result in a $\mathrm{pH}$ decrease (Soetaert et al., 2007). The colors designated for each respiration pathway are the color of respective arrow in Figure 2.

\begin{tabular}{|c|c|c|c|c|}
\hline Reaction & Stoichiometry & $\triangle \mathrm{DIC}$ & $\triangle \mathrm{ALK}$ & $\mathrm{pH}$ \\
\hline Aerobic respiration & $4 \mathrm{C}_{106} \mathrm{H}_{175} \mathrm{O}_{42}+515 \mathrm{O}_{2} \rightarrow 424 \mathrm{CO}_{2}+350 \mathrm{H}_{2} \mathrm{O}$ & 1 & 0 & 5.18 \\
\hline Denitrification & $2 \mathrm{C}_{106} \mathrm{H}_{175} \mathrm{O}_{42}+206 \mathrm{NO}_{3}^{-}+206 \mathrm{H}^{+} \rightarrow 212 \mathrm{CO}_{2}+103 \mathrm{~N}_{2}+278 \mathrm{H}_{2} \mathrm{O}$ & 1 & 1.0 & 6.78 \\
\hline Manganese reduction & $2 \mathrm{C}_{106} \mathrm{H}_{175} \mathrm{O}_{42}+515 \mathrm{MnO}_{2}+1030 \mathrm{H}^{+} \rightarrow 212 \mathrm{CO}_{2}+515 \mathrm{Mn}^{2+}+690 \mathrm{H}_{2} \mathrm{O}$ & 1 & 4.9 & + \\
\hline Iron reduction & $2 \mathrm{C}_{106} \mathrm{H}_{175} \mathrm{O}_{42}+515 \mathrm{Fe}_{2} \mathrm{O}_{3}+2060 \mathrm{H}^{+} \rightarrow 212 \mathrm{CO}_{2}+1030 \mathrm{Fe}^{2+}+1205 \mathrm{H}_{2} \mathrm{O}$ & 1 & 9.7 & + \\
\hline Sulfate reduction & $8 \mathrm{C}_{106} \mathrm{H}_{175} \mathrm{O}_{42}+515 \mathrm{SO}_{4}^{2-}+1030 \mathrm{H}^{+} \rightarrow 848 \mathrm{CO}_{2}+515 \mathrm{H}_{2} \mathrm{~S}+700 \mathrm{H}_{2} \mathrm{O}$ & 1 & 1.2 & 6.72 \\
\hline Methanogenesis & $8 \mathrm{C}_{106} \mathrm{H}_{175} \mathrm{O}_{42}+330 \mathrm{H}_{2} \mathrm{O} \rightarrow 333 \mathrm{CO}_{2}+515 \mathrm{CH}_{4}$ & 1 & 0 & 5.56 \\
\hline AOM & $8 \mathrm{C}_{106} \mathrm{H}_{175} \mathrm{O}_{42}+515 \mathrm{SO}_{4}{ }^{2-}+1030 \mathrm{H}^{+} \rightarrow 848 \mathrm{CO}_{2}+515 \mathrm{H}_{2} \mathrm{~S}+700 \mathrm{H}_{2} \mathrm{O}$ & 1 & 1.2 & 7.88 \\
\hline Sulfide oxidation & $1 \mathrm{H}_{2} \mathrm{~S}+2 \mathrm{O}_{2} \rightarrow \mathrm{SO}_{4}^{2-}+2 \mathrm{H}^{+}$ & 0 & -2 & - \\
\hline Iron oxidation & $4 \mathrm{Fe}^{2+}+4 \mathrm{H}_{2} \mathrm{O}+\mathrm{O}_{2} \rightarrow 2 \mathrm{Fe}_{2} \mathrm{O}_{3}+8 \mathrm{H}^{+}$ & 0 & -8 & - \\
\hline
\end{tabular}

geobiological processes. Interestingly, these relationships show two mutually exclusive paths that result in favorable chemistry for crystal fan formation. One, in anoxic environments with anaerobic metabolisms above $\triangle \mathrm{ALK}=0.8, \Omega_{\text {aragonite }}$ of the sediment box does not drop below one, even with high rates of organic matter delivery $\left(500 \mu \mathrm{mol} \mathrm{kg} \mathrm{kg}^{-1}\right)$. And two, if organic matter delivery is sufficiently low

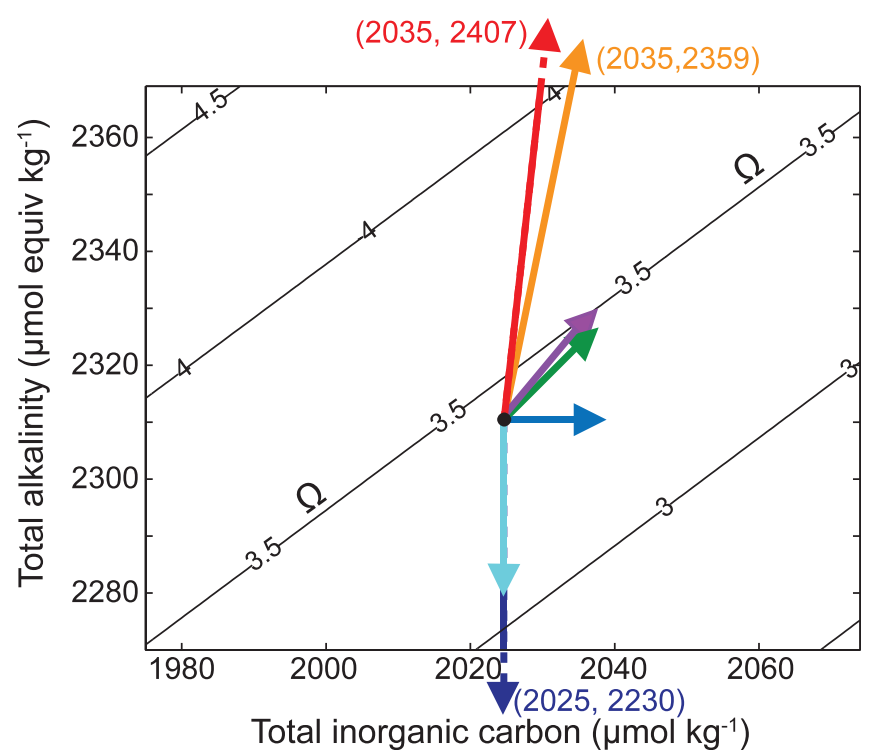

FIGURE 2-Effect of different respiratory metabolisms on dissolved inorganic carbon (DIC), alkalinity, and $\Omega_{\text {aragonite }}$ in a hypothetical environment when $10 \mu \mathrm{mol}$ $\mathrm{kg}^{-1}$ organic carbon is respired. The plot shows contours of equal $\Omega_{\text {aragonite }}$ as a function of DIC and total alkalinity. The different colored vectors describe specific redox reactions shown in Table 3. $\left(<50 \mu \mathrm{mol} \mathrm{kg}^{-1}\right)$ the sediments do not become undersaturated even when $\triangle \mathrm{ALK}$ is equal to -1 (Fig. 3 ).

\section{EXAMPLES FROM THE SEDIMENTARY RECORD}

Guided by the results of the mathematical descriptions of sedimentwater interface chemistry, we can examine examples of crystal fans from the rock record for evidence that the two solutions might have been influential in driving seafloor carbonate precipitation. Evidence of microbially mediated precipitation via anaerobic respiration pathways might include: (1) a carbon isotopic composition ${ }^{13} \mathrm{C}$-depleted relative to coeval seawater due to local organic respiration; (2) reduced authigenic minerals such as pyrite produced in close association with the precipitates; or (3) reduced metals incorporated into the carbonate structure such as $\mathrm{Fe}^{2+}$ and $\mathrm{Mn}^{2+}$. Whereas precipitation on surfaces with low organic matter delivery to the sediments might include: (1) low TOC concentrations in the interval with crystal fans; (2) incompletely reduced electron acceptors such as iron or manganese oxides; or (3) a lack of reduced minerals like pyrite.

Based on these predictions, we examined two examples of crystal fans from the Proterozoic, the Beechey Formation (Fig. 4) and the Rainstorm Member of the Johnnie Formation (Fig. 5). Both examples are intriguing because of their close association with iron-rich accessory minerals (Grotzinger and Friedman, 1989; Summa, 1993; Pruss et al., 2008).

\section{Petrographic, Spectroscopic, and Isotopic Methods}

To better understand the petrogenesis of the Beechey Formation and Johnnie Formation crystal fans, we used a variety of high-resolution in situ methods including transmitted and reflected light microscopy, scanning electron microscopy (SEM), energy dispersive spectroscopy 


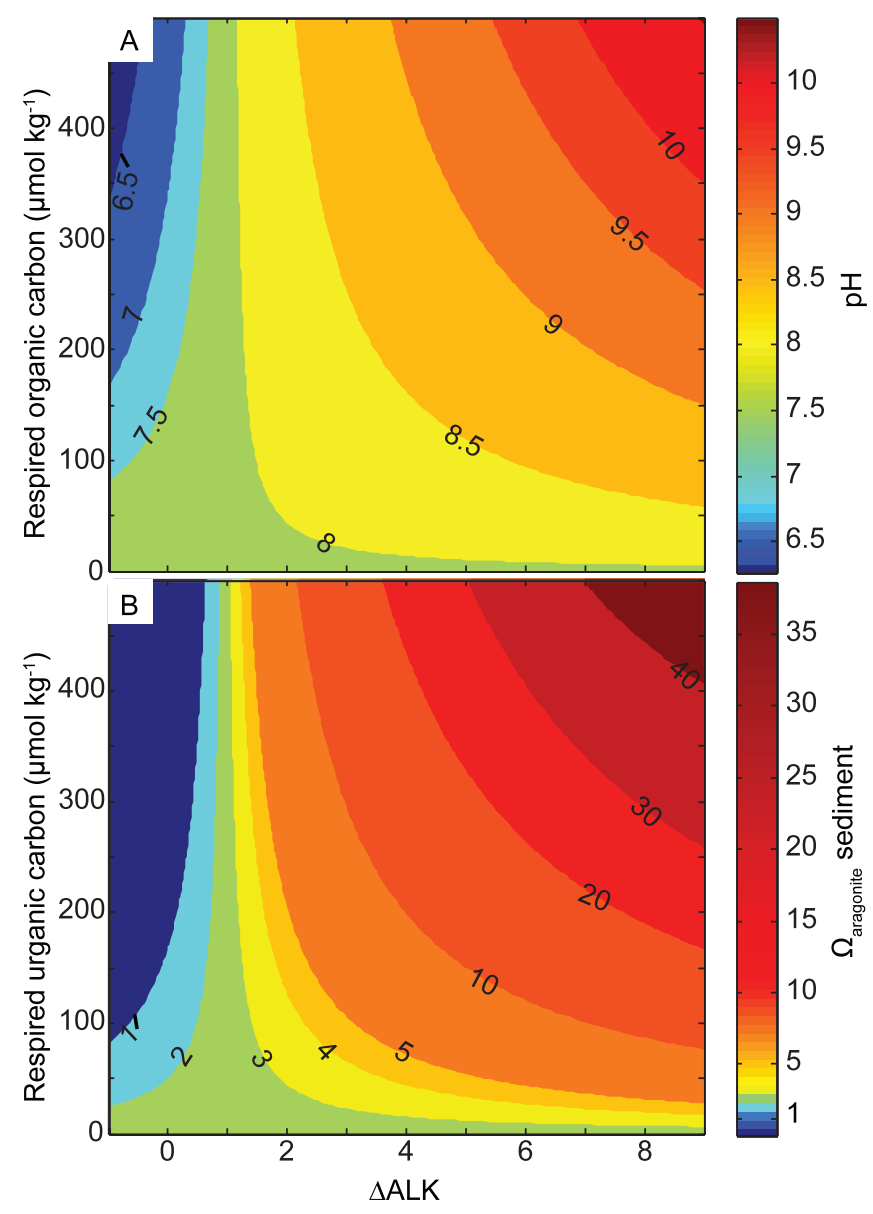

FIGURE 3-Results of the carbonate chemistry model, solved at steady state, in terms of A) $\mathrm{pH}$ and B) $\Omega_{\text {aragonite }}$ of the sediment box (Zeebe and Wolf-Gladrow, 2001). For this calculation, the water box has a fixed $\mathrm{pH}$ of 7.9 and $\Omega_{\text {aragonite }}$ of 2.36 . The results indicate both $\mathrm{pH}$ and $\left.\Omega_{\text {aragonite will drop for all } \mathrm{f}_{\mathrm{org}}(0-500 \mu \mathrm{mol} \mathrm{kg}} \mathrm{kg}^{-1}\right)$ and $\triangle$ ALK $<1$. For all $\triangle$ ALK and $\mathrm{f}_{\text {org }}<50 \mu \mathrm{mol} \mathrm{kg} \mathrm{kg}^{-1}, \Omega_{\text {aragonite }}$ remains $>1$. Additionally, $\Delta \mathrm{ALK}>\sim 2$ will result in strongly supersaturated sediment pore fluids.

(EDS), micro X-ray fluorescence $(\mu \mathrm{XRF})$, wavelength dispersive spectroscopy elemental analysis using an electron microprobe, Raman spectroscopy, and electron backscatter diffraction (EBSD). These techniques provide information on the crystallography and diagenesis of the carbonate fabrics, but also help highlight the chemistry and textures of accessory phases and surrounding sediments, which provide important insights into the chemical and physical environments of the sediment-water interface during at the time of crystal fan precipitation. The accumulation of authigenic minerals (e.g., apatite, barite, and ironbearing minerals) can provide additional information about relative crystal fan growth rates, bottom-water chemistry, organic diagenesis, and important metabolic processes that once operated at the sedimentwater interface (e.g., Fischer et al., 2009). To fully assess the character of the crystal fans and surrounding sediments we designed the following workflow: (1) petrography of representative thin sections; (2) elemental mapping at a thin-section scale using $\mu \mathrm{XRF}$; (3) mineralogical identification using Raman spectroscopy; (4) semiquantitative elemental spot analysis and elemental mapping with EDS using the Zeiss 1550 VP Field Emission Scanning Electron Microscope (SEM); and (5) quantitative elemental spot analysis and elemental mapping using the JEOL JXA-8200 Electron Microprobe on the various carbonate components to assess trace metal variations between textures and on iron oxides to estimate valence state. For all quantitative results, the accelerating voltage was $15 \mathrm{kV}$, the beam current was $20 \mathrm{nA}$, and the beam size was $1 \mu \mathrm{m}$. The CITZAF method was used for matrix correction. Sample standards for the five chemical elements analyzed, included: calcite for $\mathrm{Ca}$, dolomite for $\mathrm{Mg}$, siderite for $\mathrm{Fe}$, rhodochrosite for $\mathrm{Mn}$, strontianite for $\mathrm{Sr}$, and anhydrite for $\mathrm{S}$. Ca had an average detection limit of 170 ppm; Mg, 270 ppm; Fe, 320 ppm; Mn, 290 ppm; $\mathrm{Sr}, 490 \mathrm{ppm}$; and S, $90 \mathrm{ppm}$.

Isotopic analysis of the crystal fan pseudomorphs and surrounding matrix for the Beechey Formation was conducted at University of Michigan Stable Isotope Laboratory because no published isotopic data existed prior to this study. Ten $\mu \mathrm{g}$ of carbonate samples were weighed into stainless steal boats and heated to $200{ }^{\circ} \mathrm{C}$ under vacuum for one hour prior to reaction. Samples were then reacted in individual borosilicate reaction vessels at $77{ }^{\circ} \mathrm{C}$ for 12 minutes with 4 drops of anhydrous phosphoric acid on a Finnigan MAT Kiel IV device coupled to a Finnigan MAT 253 triple collector isotope ratio mass spectrometer. Two standards were analyzed in conjunction with the samples, NBS 18 and NBS 19, and measured precision was maintained at better than $0.1 \%$ for both carbon and oxygen isotopic compositions.

Electron backscatter diffraction (EBSD) provides a useful technique for assessing the mineralogy and replacement texture of the crystal fan samples on the SEM. Seafloor crystal fans are thought to have had an original mineralogy composed of aragonite based on the acicular morphology, feathery or square terminations, hexagonal cross sections, and botryoidal fanning growth habits (Grotzinger and Read, 1983; Sandberg, 1985; Grotzinger, 1989; Sumner and Grotzinger, 2000). Observations of crystal fans in the record reconstruct the primary texture to have consisted of acicular crystals of aragonite, bundled together to form crystal aggregates with blunt terminations. The linear, radiating fabric elements that delineate the crystal fans represent the neomorphic equivalent of these crystal bundles (Grotzinger and Read, 1983; Grotzinger, 1986; Hofmann and Jackson, 1987; Bartley et al., 2000). In all known examples, primary aragonite was replaced by a calcite or dolomite mosaic texture, or occasionally silica (Grotzinger and Read, 1983; Sumner and Grotzinger, 2000). The mosaic replacement texture varies, and can be equant, interlocking, or elongated, but importantly, the crystals composing the mosaic are not optically oriented (Sandberg, 1985; Sumner and Grotzinger, 2000).

These observations provide the basis for a method of assaying the original mineralogy and crystal form, now replaced, by mapping the optical orientation of these replacement mosaics using the electron backscatter detector (EBSD) on the SEM to obtain diffraction data (for mosaic maps generated with EBSD see Fig. 6) (Richter et al., 2011). The expected random orientation of the mosaic replacement pattern is seen in the Johnnie Formation example where the map area is within a single crystal fan pseudomorph (Figs. 6A-B). In contrast, an example of a putative aragonite crystal fan occurrence documented from the Lower Triassic Union Wash Formation, Inyo Mountains, Californiaone of the youngest observed in the sedimentary record-does not reveal the expected random grain orientations in the mosaic where the map area covers multiple blades, suggesting a primary calcite mineralogy (Figs. 6C-D) (Woods et al., 1999, 2007; Pruss et al., 2006; Woods and Baud, 2008).

\section{Paleoproterozoic Beechey Formation, Northwest Territories, Canada}

The Paleoproterozoic Beechey Formation is part of the Bear Creek Group deposited in the Kilohigok Basin 1.9 Ga (Grotzinger and McCormick, 1988). The Bear Creek Group is contemporaneous with the passive margin deposits preserved in the Wompay Orogen, but records a unique tectonic history. The lower units of the Bear Creek Group document the developing Thelon Tectonic Zone, which caused both flexural subsidence in the foredeep and arching in the nearshore environments of the foreland basin (Grotzinger and McCormick, 1988). The Bear Creek Group overlies the drowned Kimerot Platform and records rapid subsidence followed by infilling of the foreland basin. The Beechey Formation, largely comprised of shallow-marine shelf silici- 

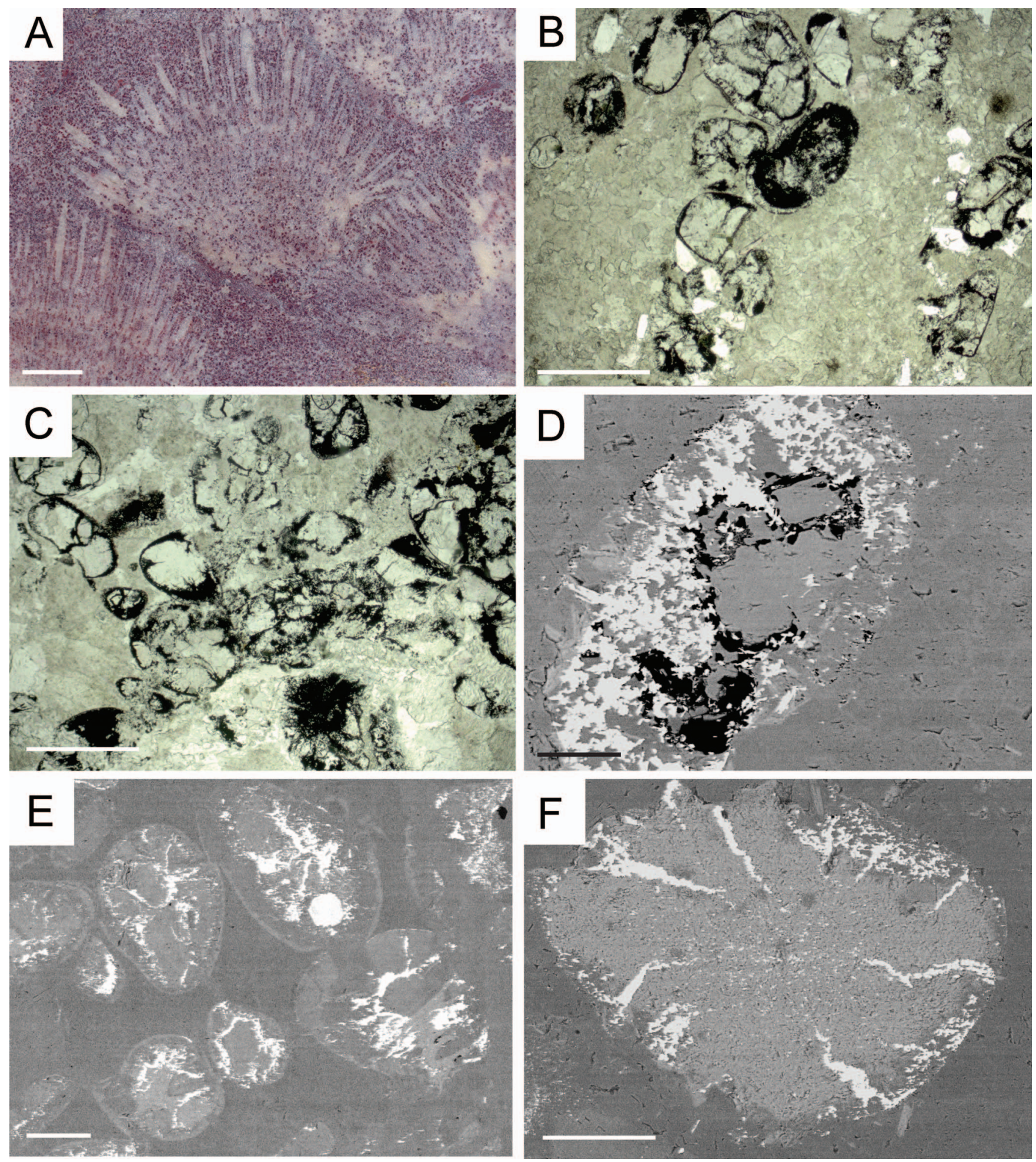

FIGURE 4-Paleoproterozoic Beechey Formation, Northwest Territories. A) Aragonite pseudomorphs display a radiating fanning morphology. Scale bar is $1 \mathrm{~cm}$. B-C) Photomicrographs of the linear aragonite pseudomorphs with grains infilling around them. The opaque coatings are hematite and chert. Scale bars are $500 \mu \mathrm{m}$. D) SEM image of a single grain composed mostly of hematite (highest backscatter) and silica (intermingled low backscatter). The angular clasts in the center of the grain are dolomite. Scale bar is $40 \mu \mathrm{m}$. E) SEM image of grains of mixed mineralogy infilling around the aragonite pseudomorphs. The mineral with high backscatter is hematite and one round apatite grain, the mineral with medium backscatter is an illite-like clay mineral (in wt $\%: \sim 1 \%-2 \% \mathrm{Mg}, 14.5 \% \mathrm{Al}, 25.5 \% \mathrm{Si}, 9 \% \mathrm{~K}, 3 \%-4 \% \mathrm{Fe}$ ) and the low backscatter matrix is dolomite. Scale bar is $200 \mu \mathrm{m}$. F) SEM image of a single grain with hematite (high backscatter) filling in cracks within clay mineral. Scale bar is $100 \mu \mathrm{m}$.

clastics, overlies deeper-water submarine fan deposits of the Rifle Formation (Grotzinger and McCormick, 1988). The crystal fans developed at the sequence boundary that marks the division between the Rifle and Beechey Formations (Grotzinger and Friedman, 1989).
The aragonite pseudomorphs form radial-fanning botryoids that grew as large as $10 \mathrm{~cm}$ wide and $30 \mathrm{~cm}$ tall. The pseudomorphs toward the center of the botryoids are narrower and increase in thickness and length toward the outside of the botryoids. The botryoids grew together 

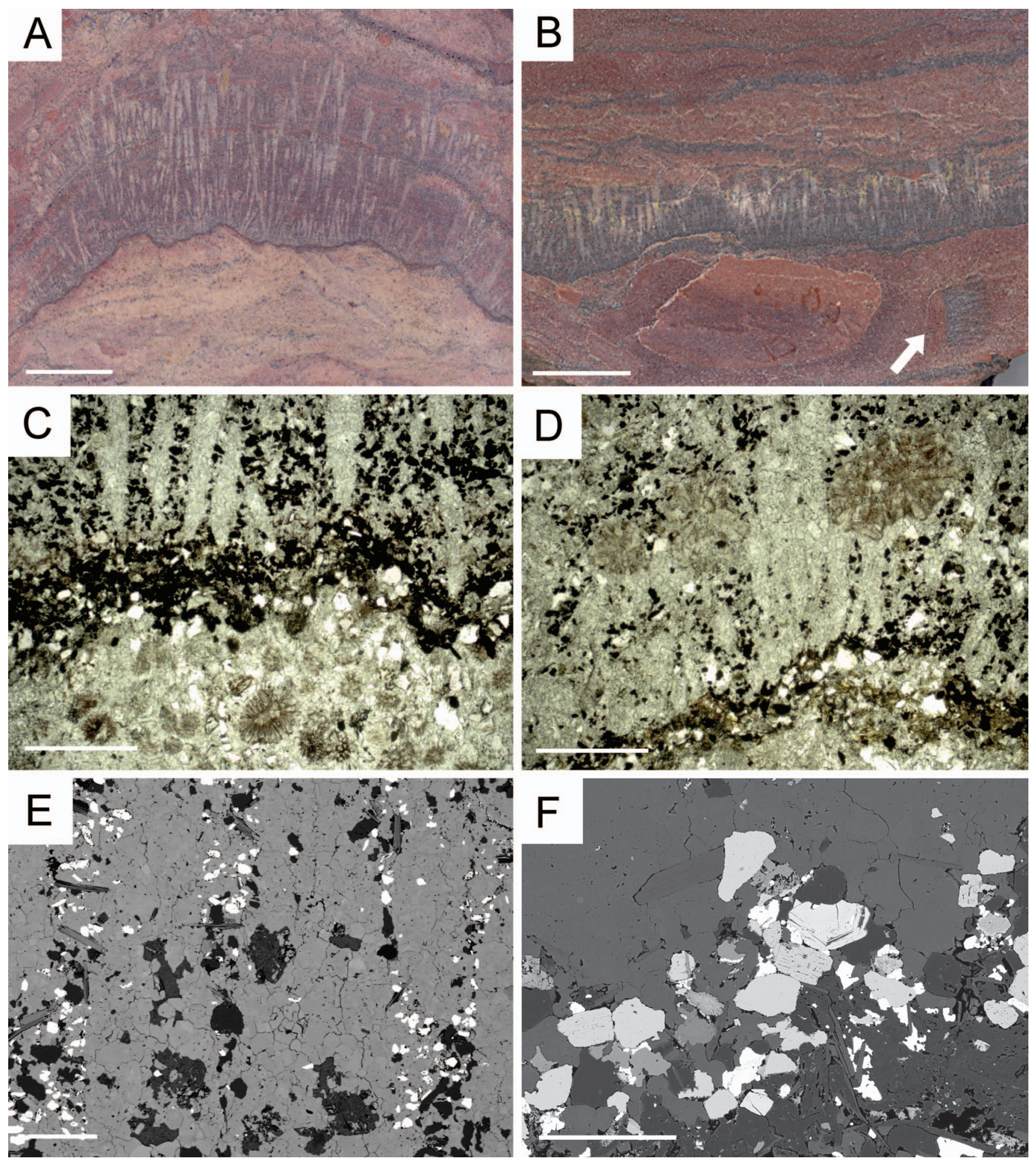

FIGURE 5-Rainstorm Member of the Ediacaran Johnnie Formation, Death Valley Region, United States. A-B) Aragonite pseudomorphs showing near-vertical growth with a fanning morphology near the nucleation point. Note the rip-up clast containing aragonite crystal fan pseudomorphs (arrow) in B. Scale bars are $1 \mathrm{~cm}$. C-D) Photomicrographs of aragonite pseudomorphs with quartz grains (white), opaque hematite and iron-titanium oxide grains, and ooids (below crystal fan nucleation horizon). Note the three ooids stopping the growth of the crystal fans in D. Scale bars are $500 \mu \mathrm{m}$. E-F) SEM images of aragonite pseudomorphs (now calcite) with detrital grains infilling around the blades. Accessory minerals include muscovite (light gray), quartz (black), hematite, iron-titanium oxides, barite (white), zircon (light-gray center of F), and rutile (white). Scale bars are $200 \mu \mathrm{m}$ and $100 \mu \mathrm{m}$, respectively.

to form deposits $1.5 \mathrm{~m}$ thick that extend laterally up to $40 \mathrm{~km}$ (Grotzinger and Friedman, 1989). Iron-coated aggregate grains of chert, iron-rich clay, and carbonate fill in between and highlight the carbonate crystal fan pseudomorphs (Fig. 4).
The mineralogy of the grains infilling around the crystal fans helps inform the sedimentary geochemistry of this environment. $\mu \mathrm{XRF}$ mapping was completed on a thin section sample of the Beechey Formation crystal fans using a $100 \mu \mathrm{m}$ resolution for $\mathrm{Ca}, \mathrm{Mg}, \mathrm{Al}, \mathrm{Si}, \mathrm{S}$, 

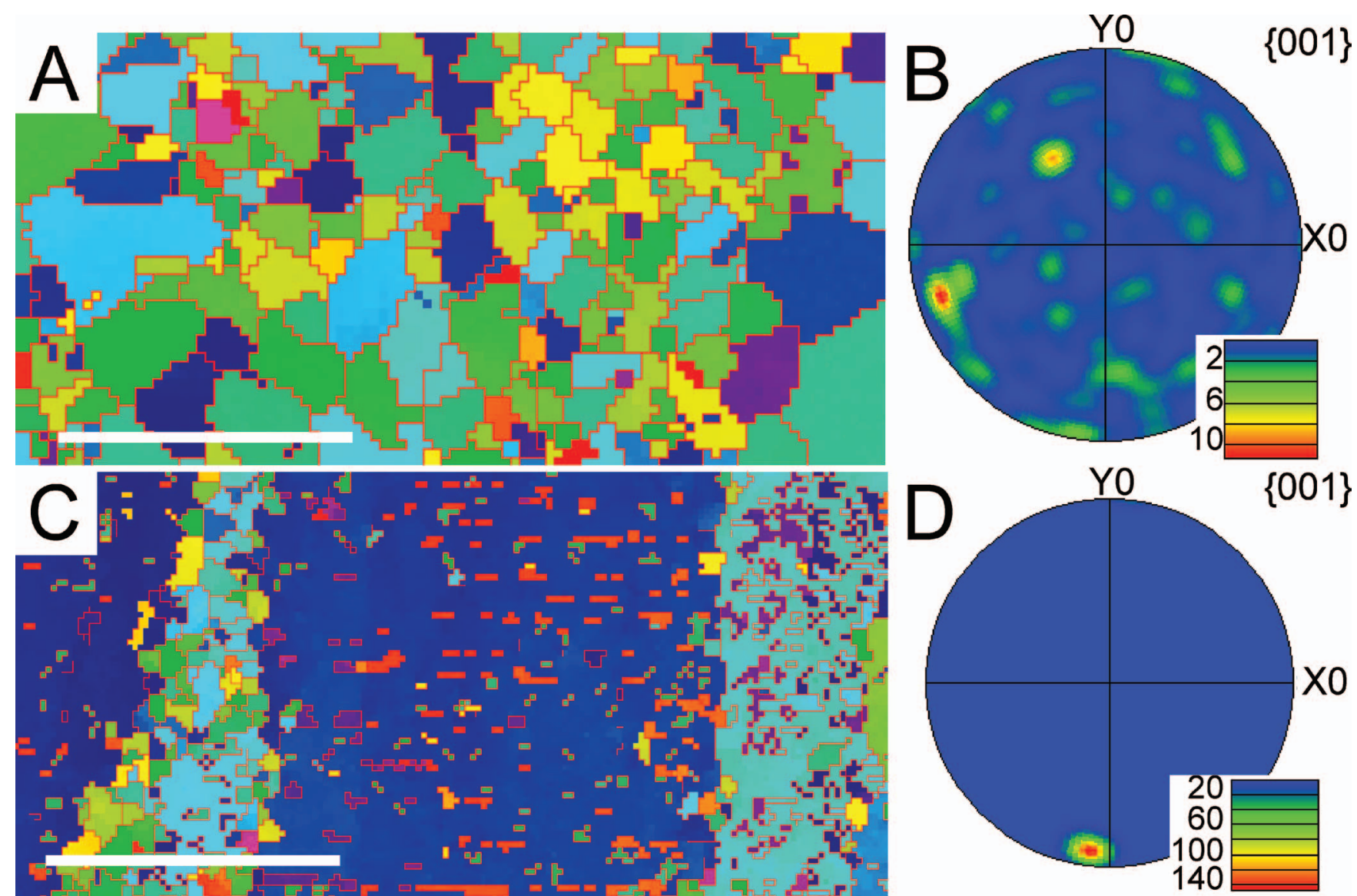

FIGURE 6-SEM mosaic images of the Johnnie Formation and the Union Wash Formation made using the electron backscatter detector (EBSD). A) Crystal orientation map within a single aragonite pseudomorph from the Johnnie Formation ( $3 \mu \mathrm{m}$ window). This example shows a calcite mosaic fabric has replaced the original aragonite. Scale bar is $100 \mu \mathrm{m}$. B) C-axis pole figure of the crystal orientation map indicates no preferential orientation of the calcite mosaic. C) Crystal orientation map through three fibrous calcite blades from the Union Wash Formation showing no replacement mosaic $(10 \mu \mathrm{m}$ window). Scale bar is $500 \mu \mathrm{m}$. D) C-axis pole figure of the crystal orientation maps indicate the calcite blades are oriented parallel to the c-axis indicating length-fast calcite.

$\mathrm{K}, \mathrm{Fe}, \mathrm{Ti}, \mathrm{Mn}$, and $\mathrm{Sr}$. $\mathrm{Ca}, \mathrm{Fe}$, and $\mathrm{Si}$ elemental distribution maps of the Beechey crystal fans are shown in Figures $7 \mathrm{~A}-\mathrm{C}$. The elemental distribution of calcium clearly highlights the individual carbonate pseudomorphs within two botryoidal fans (Fig. 7A). The elemental distribution of iron shows essentially the negative image, faintly outlining the individual pseudomorphs as well as the space between the two botryoids (Fig. 7B). Finally the silicon map shows three quartz veins crosscutting the two botryoids as well as clastic sediment fill between the crystal fan blades (Fig. 7C).

Photomicrographs and SEM analysis of individual authigenic grains that accumulated around the pseudomorphs reveal interesting morphologies (Figs. 4B-F). Most grains are round to subspherical, and, based on EDS analysis, are aggregates with an authigenic iron-silica coating. The coatings cement dolomite, quartz, and an illite-like clay mineral composed primarily of $\mathrm{Al}, \mathrm{Si}, \mathrm{K}, \mathrm{Fe}$, and $\mathrm{Mg}$ (Figs. 4D-F). In addition to grain coatings, the iron-silica precipitates cement the interiors of the grains (Figs. 4D-E) and fill internal syneresis cracks (Fig. 4F). The interlocking iron-silica precipitate texture is best seen in Figure 4D. These grains are similar in texture and composition to those known from Paleoproterozoic-age Circum-Superior granular iron formations (Klein and Fink, 1976; Simonson, 1985, 1987; Beukes and Klein, 1990).

Quantitative trace metal analysis (Ca, Mg, Sr, Fe, Mn, and S) of five different carbonate phases were analyzed using an electron microprobe. A backscatter image and elemental abundance maps of $\mathrm{Mg}, \mathrm{Fe}$, and Mn of a single crystal fan blade highlighted by iron oxide-coated grains is shown in Figures 8A-D. Quantitative spot analyses of five distinguishable fabrics were analyzed to calibrate the intensity maps - dark crystal fan pseudomorph (dcf), medium intensity cements in the crystal fan pseudomorph (mcf), light intensity cements in the crystal fan pseudomorph (lcf), light intensity dolomite within aggregate grains (lc), and dark intensity carbonate associated with the iron oxide coatings on the aggregate grains (dc) (Fig. 8A). The three generations of pseudomorph replacement textures are appreciably distinct, with clear zonation in the medium and light cement phases suggesting slow replacement and reprecipitation of the crystal fan blades. The different phases have strikingly different trace metal incorporation, particularly in iron and manganese. The medium-zoned crystal fan cement shows the highest manganese incorporation (avg. $4300 \mathrm{ppm} \mathrm{Mn),} \mathrm{whereas} \mathrm{the}$ lightest, final cement phase is highest in iron (avg. $5.2 \mathrm{wt} \% \mathrm{Fe}$ ). The other phases have similar manganese concentrations ( $\sim 2000 \mathrm{ppm} \mathrm{Mn})$. The dolomite in the aggregate grains is similarly high in iron (avg. 5 $\mathrm{wt} \% \mathrm{Fe}$ ) but the dolomite most closely associated with the iron oxides rimming the clasts is significantly lower in iron (avg. $2.4 \mathrm{wt} \% \mathrm{Fe}$ ). These data suggest substantial amounts of reduced iron and manganese in the precipitating fluids, both early (as in the case of the dolomite within the aggregate grains) and later during diagenesis and replacement of the aragonite crystal fans. Metal enrichments this substantial likely record the effects of dissimilarity metal oxide reduction in this environment, however, the possibility of later diagenetic additions makes this difficult to conclude with certainty. Isotopic analysis of the crystal fans and surrounding matrix - a combination of cements and aggregate grains of carbonate, chert, clays, and iron oxides - was conducted to help constrain the degree to which the crystal fans incorporated light remineralized carbon during their precipitation. The crystal fans $\left(\delta^{13} \mathrm{C}_{\mathrm{VPDB}}-0.16 \%\right.$ o $0.42 \% o, 0.89 \%$; $\delta^{18} \mathrm{O}_{\mathrm{VPDB}}-10.6 \%$ o $-9.47 \%$, 

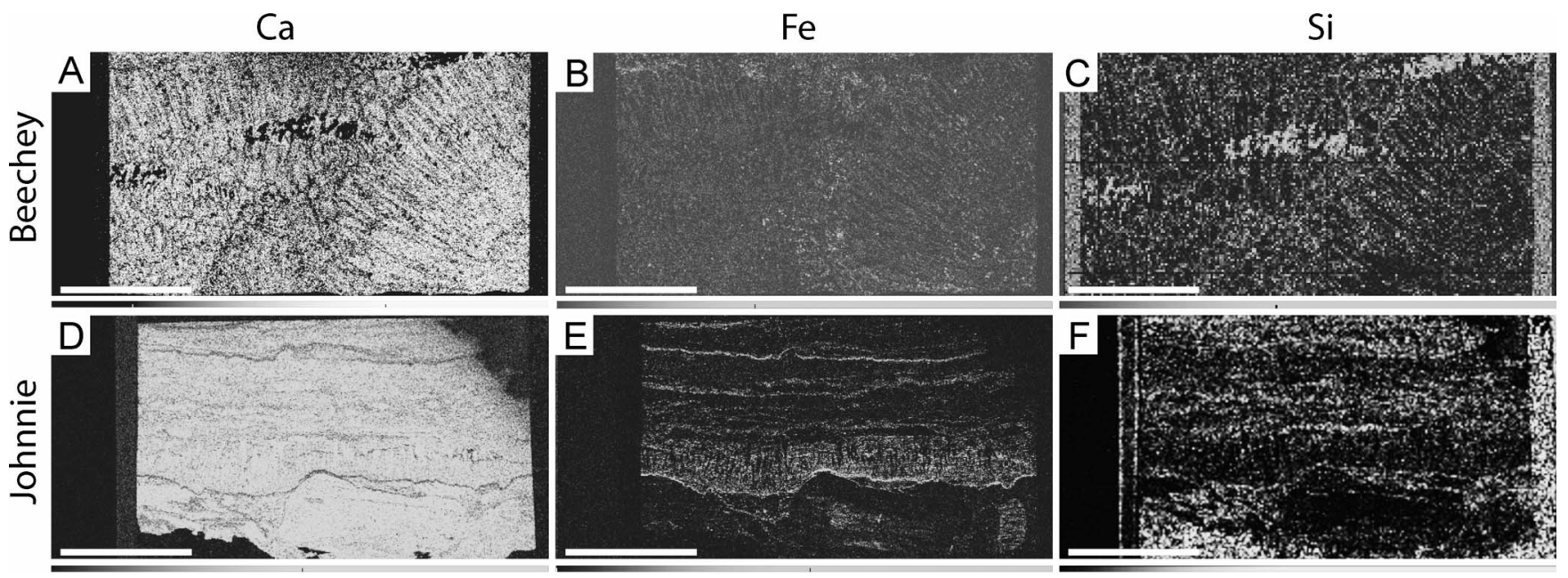

FIGURE 7- $\mathrm{XXRF}$ maps of thin sections of the Beechey Formation (A-C) and Johnnie Formation (D-F). Images are in grayscale to bring out contrast, where lighter shades correspond to an increasing rate of detector counts. A) Ca map with a range from 0 to 734 counts per second. B) Fe map with a range from 0 to 838 counts per second. C) $\mathrm{Si}$ map with a range from 0 to 524 counts per second. D) Ca map with a range from 0 to 1101 counts per second. E) Fe map with a range from 0 to 655 counts per second. F) Si map with a range from 0 to 498 counts per second. Scale bar in all images is $21 \mathrm{~mm}$.

$-9.43 \%$ ) and surrounding matrix $\left(\delta^{13} \mathrm{C}_{\mathrm{VPDB}} 0.02 \%\right.$, $0.40 \%$ o, $1.09 \%$; $\delta^{18} \mathrm{O}_{\mathrm{VPDB}}-10.69 \%$ o, $-9.11 \%$ o, $-10.06 \%$ ) show little isotopic difference between the two and neither component is substantially ${ }^{13} \mathrm{C}$ depleted, though the $\mathrm{O}$ isotope ratios suggest some postdepositional resetting. This is different than the $\mathrm{C}$ isotopic systematics commonly observed in iron formation carbonate minerals (Fischer et al., 2009), and suggests that little microbial work was required on this system to promote carbonate precipitation, perhaps due to a higher amount of DIC in seawater or a smaller biological pump, or both (Hotinski et al., 2004; Fischer et al., 2009).

\section{Neoproterozoic Johnnie Formation, Death Valley Region, United States}

The Ediacaran-age Johnnie Formation hosts crystal fans in the Rainstorm Member, in a sequence of pink and gray limestone beds 10 20 m thick (Summa, 1993; Pruss et al., 2008). The Rainstorm Member crystal fans are not associated with the Marinoan cap carbonate sequence, which in the Death Valley Region is captured within the Noonday Formation (Corsetti and Kaufman, 2003; Corsetti and Grotzinger, 2005; Petterson et al., 2011). This occurrence is one of just a few examples of aragonite seafloor crystal fans in strata between the Marinoan-age cap carbonates and the seafloor fans of Lower Triassic strata, though crystal fans reported from the Katakturuk Dolomite in Alaska might be of similar age (Table 1) (Macdonald et al., 2009b). The Rainstorm fans coincide with the nadir of a major middle Ediacaran carbon isotope anomaly $\left(-11 \%\right.$ o $\left.\delta^{13} \mathrm{C}_{\mathrm{VPDB}}\right)$ termed the Shuram excursion (e.g., Kaufman et al., 2007; Pruss et al., 2008; Bergmann et al., 2011; Grotzinger et al., 2011; Verdel et al., 2011).

The crystal fans appear gray in outcrop, forming laterally extensive sheets of variable thickness $(1-20 \mathrm{~cm})$, and are currently only observed at localities within the southern Nopah Range. The seafloor fans are interbedded with pink intraclast conglomerates and oolitic grainstones that include clasts of crystal fans lithologies (Figs. 5A-B). The individual pseudomorphs are near vertical with fanning apparent near the points of nucleation (Figs. 5A-B). The fans nucleate from horizons rich in iron minerals, and the individual blades are surrounded by iron phases (Summa, 1993; Pruss et al., 2008). $\mu$ XRF elemental mapping was completed on the Rainstorm Member crystal fans at $100 \mu \mathrm{m}$ resolution for $\mathrm{Ca}, \mathrm{Mg}, \mathrm{Al}, \mathrm{Si}, \mathrm{S}, \mathrm{K}, \mathrm{Fe}, \mathrm{Ti}, \mathrm{Mn}$, and $\mathrm{Sr}$. We observed that the horizon from which crystal fans nucleated has high iron concentrations compared to surrounding sediments, though other iron- rich laminae did not nucleate fans (Fig. 7E). EDS and Raman spectroscopy measurements were made to determine the mineralogy of the associated sediment. Nucleation horizons are comprised of a striking diversity of minerals, including calcite, dolomite, quartz, hematite, rutile and anatase (both titanium oxides), ilmenite, muscovite, biotite, zircon, apatite, barite, and monazite (Fig. 5). The hematite and titanium oxides are the most abundant minerals after calcite and quartz. The diversity of iron and titanium oxide minerals, their morphologies, relative density, and solubility characteristics altogether suggest a detrital origin (Figs. 5C-F). Sedimentation of both hematite and iron-titanium oxide phases persist above the crystal fan nucleation horizon and infill around the crystal fans (Figs. 5C-F). We used the relative backscatter contrast on the SEM to estimate and compare the mineral abundances of the intraclast ooid grainstone versus the crystal fan interval. The intraclast ooid grainstone is $\sim 75 \%$ calcite, $20 \%$ quartz, and 5\% minerals with high backscatter (i.e., hematite). The crystal fan region surveyed is $\sim 70 \%$ calcite, $10 \%$ dolomite, $10 \%$ quartz, and $10 \%$ minerals with high backscatter. Trace iron phases that pigment the pink intraclast-rich limestones are concentrated within and around detrital carbonate phases like ooids and intraclasts (Figs. 5AB), whereas the iron-rich phases associated with the crystal fans are found in subspherical hematite grains. The mineral lamina that the crystal fans nucleate from could mark dissolution events that concentrated recalcitrant minerals, however, we do not favor this model because quartz is not enriched at these horizons (Fig. 7F). Consequently, dissolution-driven precipitation (like that seen in Paleozoic hardgrounds, e.g., Wilson and Palmer, 1992) is unlikely. The hematite grains remain an important component of the sediment infilling around the crystal fans and are not just in the lamina from which crystal fan growth initiated.

A backscatter image and elemental abundance maps of $\mathrm{Mg}, \mathrm{Fe}$, and $\mathrm{Mn}$ of a crystal fan horizon highlighted by iron and titanium oxides is shown in Figures 9A-D. Quantitative trace metal analyses (Ca, Mg, $\mathrm{Sr}, \mathrm{Fe}, \mathrm{Mn}$, and $\mathrm{S}$ ) of four distinguishable carbonate fabrics were completed to calibrate the intensity maps - matrix cement below the crystal fan interval (pc), ooids below the crystal fan interval (oo), crystal fan pseudomorphs (cf), and cement filling around the crystal fan pseudomorphs and between iron oxide grains (cfc) (Fig. 9A). The crystal fan pseudomorphs had the lowest concentration of iron and the highest of manganese (avg. 460 ppm Fe, avg. 680 ppm Mn, max. $3580 \mathrm{ppm} \mathrm{Mn}$ ). In contrast, the ooids were highest in iron (avg. $6400 \mathrm{ppm} \mathrm{Fe}, \max 42,000 \mathrm{ppm}$ Fe) although some of this signal is 


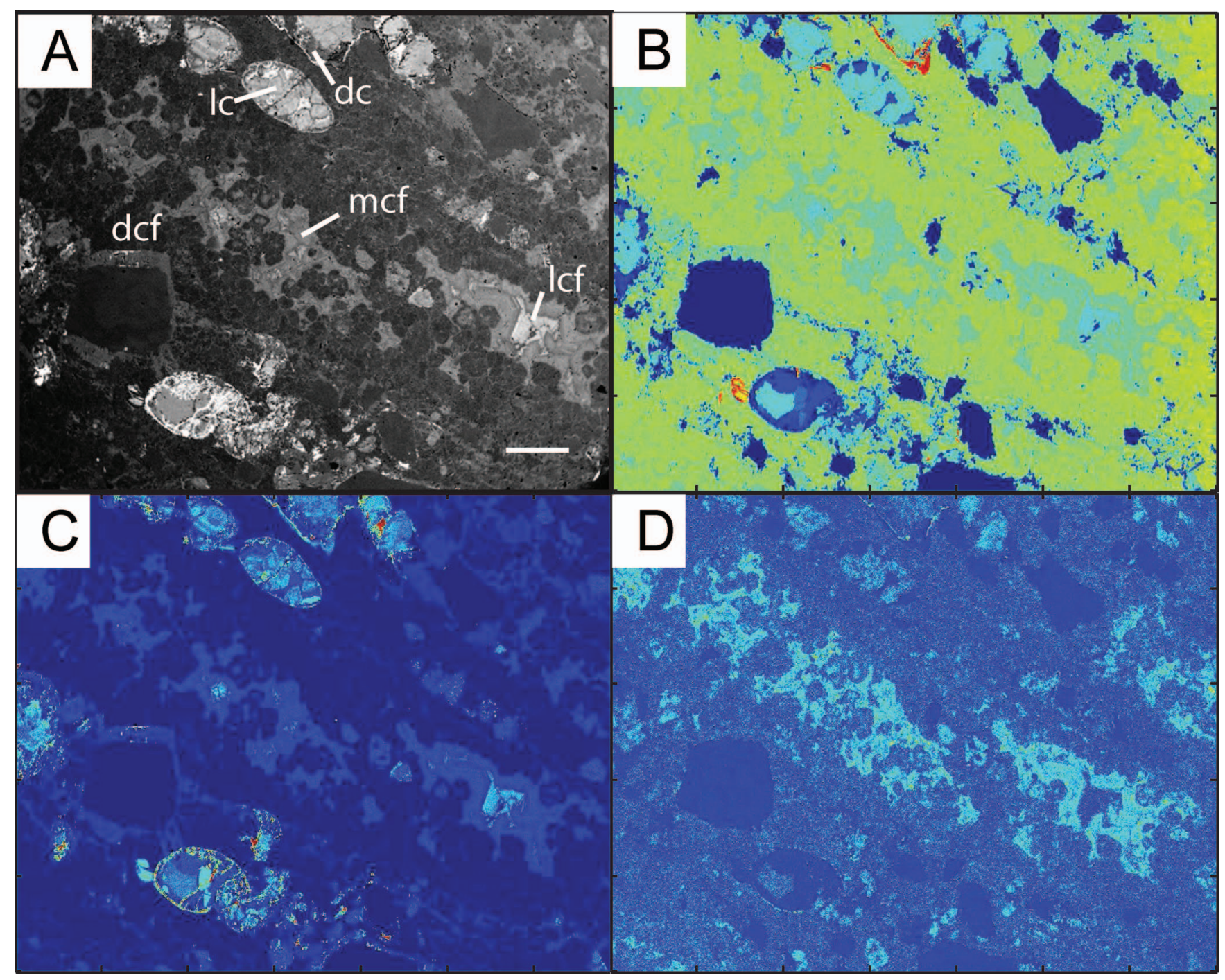

FIGURE 8-Electron microprobe maps of trace elements in the carbonate phases of the Beechey Formation. A) Backscatter image of a single crystal fan pseudomorph highlighted by accessory grains. Five carbonate textures were identified: dark crystal fan pseudomorph $=$ dcf, medium intensity cements in the crystal fan pseudomorph $=$ mcf, light intensity cements in the crystal fan pseudomorph $=\mathrm{lcf}$, light intensity dolomite within aggregate grains $=$ lc, dark intensity carbonate associated with the iron oxide coatings on the aggregate grains $=\mathrm{dc}$. Scale bar is $310 \mu \mathrm{m}$. B-D) Intensity maps of $\mathrm{Mg}$, Fe, and Mn, respectively. The corresponding quantitative measurements for the different carbonate phases can be found in Table 4 .

probably carried by finely disseminated iron oxides observed as small, micron-scale high-backscatter inclusions occasionally interspersed in these coated grains. The cements surrounding the crystal fans were distinct from the fans themselves and were also high in iron (avg. $4140 \mathrm{ppm}$ Fe, max. $3.2 \mathrm{wt} \% \mathrm{Fe}$ ). These results suggest that some metal reduction was likely occurring in the shallow sediments, however, a significant portion of the metals remain in higher-valent oxides (including manganese) (Figs. 9C-D). Additionally, there is no evidence of pyrite in these rocks suggesting sulfate reduction was not significant and organic matter inputs were relatively low. Altogether, these observations suggest minimal organic diagenesis and consequently little microbial work on the carbonate chemistry over environmental DIC. The lack of isotopic variability in the Johnnie Formation supports this, suggesting a wellmixed isotopic reservoir, most likely marine DIC (Pruss et al., 2008).

\section{DISCUSSION}

From the perspective of our mathematical framework there were several paths, in principle, to develop favorable chemical conditions for crystal fan growth at the sediment-water interface. One end-member solution depends on anoxic conditions and anaerobic respiration pathways that increase carbonate saturation state at the sedimentwater interface. The other end-member solution describes a scenario of low organic matter delivery to the sediments that results in little remineralized $\mathrm{CO}_{2}$ and little change to the carbonate chemistry in the shallow sediments, which-depending on the overlying seawater saturation state - could also promote seafloor crystal fan growth. These end members provide a means to evaluate observations of seafloor crystal fans from the geologic record.

Our high-resolution petrographic analysis of two different Proterozoic occurrences of seafloor-precipitated crystal fans reveals distinct features that add insight into their origin. Both examples represent discrete intervals of seafloor precipitation - within hundreds to thousands of meters of surrounding stratigraphy — and both examples coincide with assemblages of accessory minerals and aggregates that shed light on the chemical and physical conditions that led to the seafloor precipitation. Furthermore, examples from a literature review suggest other examples share similarities to the two deposits we studied.

The Beechey Formation crystal fans are notable for their cooccurrence with authigenic iron-silica minerals. These authigenic minerals formed and were deposited with the crystal fans during marine transgression, which is a common sequence stratigraphic 
TABLE 4-Quantitative measurements of $\mathrm{Mg}, \mathrm{Fe}$, and $\mathrm{Mn}$ from the five identified carbonate phases of the Beechey Formation (Fig. 8) and four phases of the Johnnie Formation (Fig. 9). The results are presented as average weight percent, maximum weight percent, minimum weight percent, standard deviation of measurements, and \# of spot analyses from each phase.

\begin{tabular}{lcrrrrc}
\hline \hline & & & & & & $\#$ \\
Carbonate phase & Metal & Avg. \% & Max. \% & Min. \% & Std. dev. & Analyses \\
\hline Beechey DCF & $\mathrm{Mg}$ & 13.635 & 15.087 & 11.242 & 0.486 & 65 \\
Beechey MCF & $\mathrm{Mg}$ & 12.370 & 14.179 & 10.048 & 0.783 & 64 \\
Beechey LCF & $\mathrm{Mg}$ & 10.673 & 12.708 & 9.594 & 0.699 & 26 \\
Beechey LC & $\mathrm{Mg}$ & 10.619 & 13.399 & 9.224 & 0.588 & 43 \\
Beechey DC & $\mathrm{Mg}$ & 12.654 & 14.294 & 10.157 & 1.046 & 21 \\
Johnnie PC & $\mathrm{Mg}$ & 0.201 & 0.525 & 0.081 & 0.097 & 50 \\
Johnnie OO & $\mathrm{Mg}$ & 0.232 & 0.411 & 0.115 & 0.067 & 31 \\
Johnnie CF & $\mathrm{Mg}$ & 0.195 & 0.413 & 0.01 & 0.087 & 66 \\
Johnnie CFC & $\mathrm{Mg}$ & 0.209 & 0.402 & 0.089 & 0.075 & 36 \\
Beechey DCF & $\mathrm{Fe}$ & 0.345 & 2.397 & 0.050 & 0.509 & 65 \\
Beechey MCF & $\mathrm{Fe}$ & 2.642 & 6.043 & 0.041 & 1.133 & 64 \\
Beechey LCF & $\mathrm{Fe}$ & 5.241 & 7.079 & 1.886 & 1.399 & 26 \\
Beechey LC & $\mathrm{Fe}$ & 5.088 & 6.235 & 1.692 & 0.739 & 43 \\
Beechey DC & $\mathrm{Fe}$ & 2.467 & 5.850 & 1.385 & 1.218 & 21 \\
Johnnie PC & $\mathrm{Fe}$ & 0.105 & 2.120 & 0.000 & 0.338 & 50 \\
Johnnie OO & $\mathrm{Fe}$ & 0.644 & 4.156 & 0.019 & 0.944 & 31 \\
Johnnie CF & $\mathrm{Fe}$ & 0.046 & 0.173 & 0.000 & 0.039 & 66 \\
Johnnie CFC & $\mathrm{Fe}$ & 0.414 & 3.298 & 0.050 & 0.692 & 36 \\
Beechey DCF & $\mathrm{Mn}$ & 0.191 & 0.621 & 0.100 & 0.071 & 65 \\
Beechey MCF & $\mathrm{Mn}$ & 0.431 & 0.986 & 0.100 & 0.176 & 64 \\
Beechey LCF & $\mathrm{Mn}$ & 0.192 & 0.351 & 0.109 & 0.073 & 26 \\
Beechey LC & $\mathrm{Mn}$ & 0.258 & 0.435 & 0.112 & 0.061 & 43 \\
Beechey DC & $\mathrm{Mn}$ & 0.178 & 0.353 & 0.105 & 0.061 & 21 \\
Johnnie PC & $\mathrm{Mn}$ & 0.026 & 0.112 & 0.000 & 0.026 & 50 \\
Johnnie OO & $\mathrm{Mn}$ & 0.041 & 0.130 & 0.000 & 0.030 & 31 \\
Johnnie CF & $\mathrm{Mn}$ & 0.068 & 0.358 & 0.000 & 0.084 & 66 \\
Johnnie CFC & $\mathrm{Mn}$ & 0.057 & 0.254 & 0.000 & 0.060 & 36 \\
\hline & & & & & & \\
\hline
\end{tabular}

occurrence for authigenic iron-mineral precipitation, as the transgressing shoreline floods rivers and slows the delivery of detrital sediment to offshore paleoenvironments (Burkhalter, 1995; Simonson and Hassler, 1996; Fralick and Pufahl, 2006). In addition, the Beechey Formation crystal fans may have benefited from an environment wherein ferric iron served as an important electron acceptor for the respiration of organic matter. Iron reduction provides a strong alkalinity pump with a $\triangle \mathrm{ALK}$ of 9.7 promoting an increase in the carbonate saturation state of the sediments. This alkalinity boost was probably somewhat offset by iron cycling in this environment because of ferrous iron oxidation ( $\triangle \mathrm{ALK} \sim-8)$, though the net effect of this iron cycling was likely to turn ferric iron into mixed-valence and ferrous iron silicates (e.g., Fischer et al., 2009). Evidence that this was occurring can be inferred by the very high concentrations of reduced iron incorporated into the carbonates (3500 ppm-5 wt \%). A corresponding ${ }^{13} \mathrm{C}$-depletion in the crystal fan pseudomorphs from a remineralized organic component, however, is not readily apparent. That in mind, with the large alkalinity contribution from iron and manganese reduction, they improve the favorability of carbonate precipitation with smaller amounts of organic carbon. Caution is required because reduced metals are often incorporated into calcite and dolomite during burial diagenesis and recrystallization as diagenetic fluids are often reducing and carry enriched concentrations in these metals over seawater. Systematic differences between the different phases of carbonate (clasts in the aggregate grains vs. the multiple phases replacing the crystal fans), however, suggest that whole-rock homogenization did not occur during diagenesis. Instead the crystal fans display a dolomite replacement sequence of the original aragonite beginning with an amorphous low iron, low manganese phase replacing the aragonite along the edges of the fan, an equant-zoned high-manganese dolomite replacing the interior of the fans, and a final equant region of high iron dolomite in the core of the replacement cement. The development of incipient granular iron formation associated with the crystal fans suggests metal oxides used in respiration of the organic matter advected to this environment would have supplied alkalinity to buffer and/or increase the saturation state and promote crystal fan nucleation and growth. The crystal fans in the Beechey Formation sit on a hiatal surface that marks the sequence boundary between the Rifle and Beechey formations (Grotzinger and Friedman, 1989). They were deposited during a transgression that resubmerged the shelf and are locally thickest where the condensed interval overlies the hiatal exposure surface. Sediment starvation associated with the condensed interval likely contributed to the favorable conditions leading to crystal fan formation (Grotzinger and Friedman, 1989). This context suggests that sedimentation rate in the Proterozoic examples may be another important control on crystal fan occurrences, as the Beechey Formation fans only appeared in the stratigraphy when sedimentation rates were lowest.

Our model results also provide helpful insights into the crystal fans that occur in the Johnnie Formation, which may have developed during an interval of reduced organic carbon flux to the seafloor and during a period of increased detrital metal oxide inputs. Like the Beechey Formation occurrence, these fans also co-occur with iron-bearing minerals. High-resolution microscopy shows that the iron is present primarily as ferric iron in accessory phases (mainly hematite but is also present in ilmenite and biotite). There are a few possibilities to explain the association between crystal fans and dense detrital accessory minerals. These include: (1) the dense minerals are a component of a wind-winnowed deposit (grain size between 10 and $100 \mu \mathrm{m}$ ); or (2) the heavy mineral laminae represent lag deposits where water winnowing removed less dense and finer grains. The seafloor was storm dominated, as evidenced by abundant rip-up intraclasts and hummocky crossstratification, but in the maximum flooding interval, new sediment supply would have been diminished resulting in winnowing and density sorting of the grains. The mineral assemblage implies that the seafloor was oxic at the time of deposition with relatively little organic matter delivery to the seafloor. The relative abundance of sedimentary organic matter can be inferred from the ferric iron-bearing secondary mineral assemblage because these phases are vulnerable to both early and late diagenetic destruction from the reducing power of organic matter (e.g., Walker, 1984; Poulton et al., 2004; Fischer and Knoll, 2009). This inference is also supported by the presence of barite in this sample (Fig. 6), which also would have been differentially susceptible to reductive dissolution. Empirically, these rocks contain exceedingly little residual organic carbon (Kaufman et al., 2007). The isotopic composition of the crystal fan pseudomorphs and the surrounding matrix does suggest a large component of remineralized organic carbon; however, because the two phases not show systematic differences that would have resulted from organic matter respiration in shallow sediments or at the sediment-water interface, the depleted DIC source was likely well mixed (Pruss et al., 2008). Our model suggests that under aerobic conditions, if the organic carbon input is $<50 \mu \mathrm{mol} \mathrm{kg} \mathrm{kg}^{-1}$ or thereabouts, the sediment-water interface will remain supersaturated $\left(\Omega_{\text {aragonite }} \sim 2.5\right)$. Similar to the Beechey Formation crystal fans, the crystal fan beds in the Johnnie Formation also sit within a transgressive to highstand systems tract that begins with deposition of the Johnnie oolite (Summa, 1993; Bergmann et al., 2011). The pink limestones that contain the crystal fan beds have been interpreted as the maximum flooding interval on the basis of their sedimentology, sequence stratigraphy, and carbon isotope systematics (Summa, 1993; Bergmann et al., 2011; Grotzinger et al., 2011). In this scenario, the crystal fans grew during a period of low background sedimentation corresponding to maximum flooding - a similar sequence stratigraphic context to the Beechey fans.

\section{Other Examples from the Rock Record}

Our analysis here helps contextualize additional crystal fan occurrences in the sedimentary record (Table 1). Prior to the rise of 


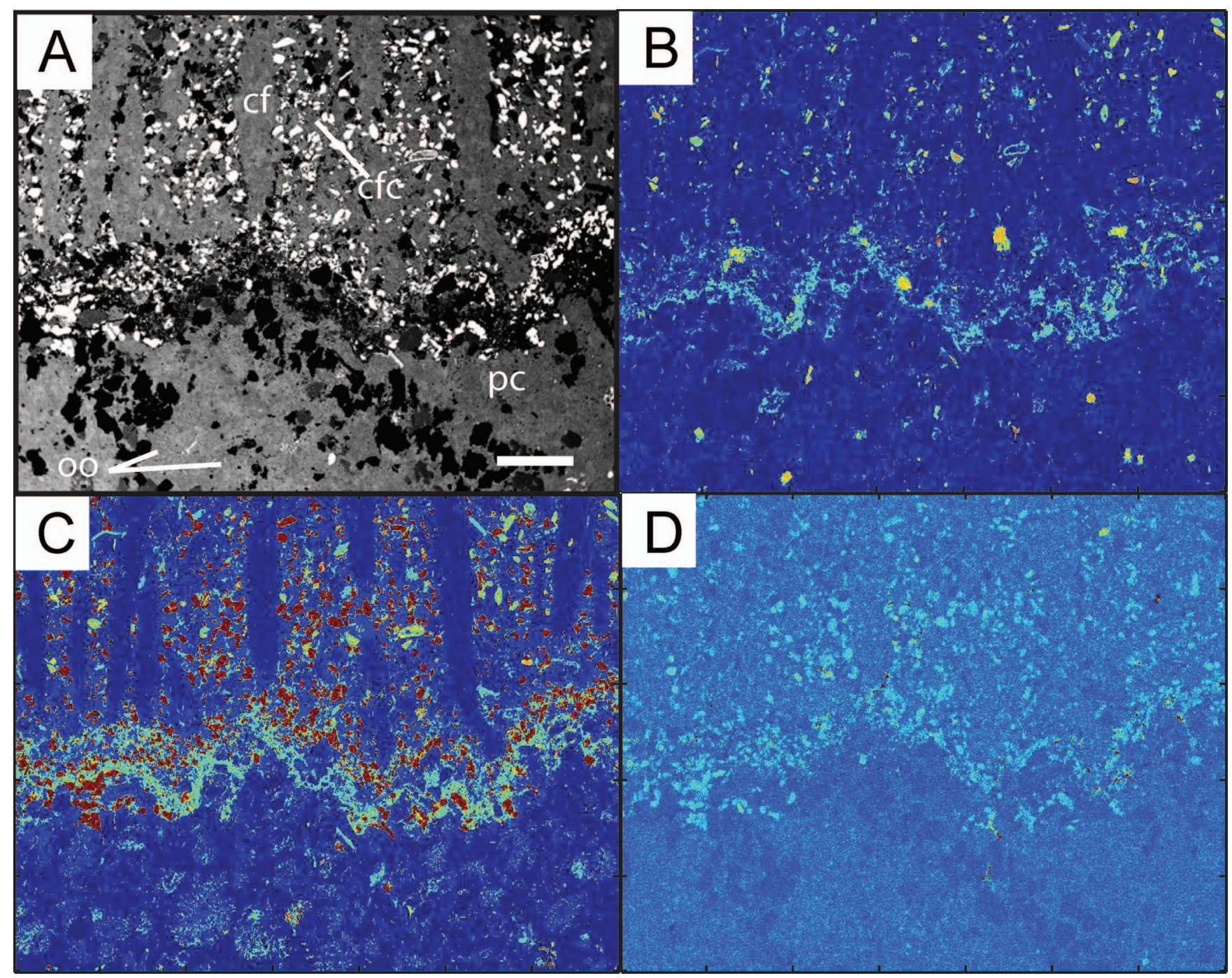

FIGURE 9-Electron microprobe maps of trace elements in the carbonate phases of the Johnnie Formation. A) Backscatter image of a crystal fan horizon highlighted by accessory grains. Four carbonate textures were identified: matrix cement below the crystal fan interval $=$ pc, ooids below the crystal fan interval $=$ oo, crystal fan pseudomorphs $=\mathrm{cf}$, and cement filling around the crystal fan pseudomorphs and between iron oxide grains = cfc. Scale bar is $310 \mu \mathrm{m}$. B-D) Intensity maps of Mg, Fe, and Mn. The corresponding quantitative measurements for the different carbonate phases can be found in Table 4 .

oxygenic photosynthesis, electron donors limited primary productivity (Kharecha et al., 2005; Fischer and Knoll, 2009), and consequently, organic fluxes to the sediment-water interface were likely substantially lower than today. This implies that the abundant crystal fan occurrences in Archean carbonate platforms, which are present across a range of shallow subtidal to supratidal paleoenvironmental settings (Sumner and Grotzinger, 2004), may have been due to a reduced flux of organic matter to the seafloor, in addition to the general lack of aerobic respiratory metabolisms at that time (Higgins et al., 2009). After the rise of oxygen in Paleoproterozoic time, aerobic metabolisms would have begun to impact the carbonate chemistry of the seafloor. The continued occurrence of seafloor crystal fans well into Paleoproterozoic time, however, may reflect higher DIC concentrations in seawater due to the faint young sun and higher $\mathrm{pCO}_{2}$ (Grotzinger and Kasting, 1993; Bartley and Kah, 2004; Fischer et al., 2009). Higher amounts of DIC would buffer the carbonate chemistry of the sediment-water interface and shallow sediments against undersaturation, despite increasing amounts of organic delivery and aerobic respiration occurring on the seafloor and in surface sediments. As geological time wore on, and $\mathrm{pCO}_{2}$, and DIC concentrations in the atmosphere and seawater decreased, promoting larger gradients in seawater saturation state and undersaturation of most seafloor settings (Higgins et al., 2009), crystal fans were limited to times of carbon cycle perturbations.

Many Proterozoic crystal fans contain sedimentologic similarities to the Beechey and Johnnie formations crystal fans (Table 1). Multiple examples co-occur with detrital lag deposits (Cheshire Formation, Gaoyuzhuang Formation) and more specifically with hematite grains and coatings (Odjick-Rocknest Boundary, Maieberg Formation, Alwa Formation) although the details of the accessory sediments have not been examined in as much detail in these examples. Interestingly, several examples are also associated with pink, metal-rich limestones and the potential implication of this association bears further study (Teena Formation, Bambui Group, Maieberg Formation). Results from trace metal analysis of the Beechey and Johnnie Formations suggest these other examples of pink carbonates may also have substantially elevated concentrations of reduced $\mathrm{Fe}$ and/or $\mathrm{Mn}$ incorporated in the carbonate phase. The broad sequence stratigraphic context and low background sedimentation rate behavior is also observed for Neoproterozoic crystal fans that developed within the inferred interval of maximum flooding between the cap dolostones and overlying sediments during Marinoan postglacial sea level rise (OdjickRocknest Boundary, Maieberg Formation, Mt. Doreen Formation, 
Bushmansklippe Formation, Hayhook Formation, Mirasol d'Oeste Formation, Ol Member, Tsagaan Oloom Formation, Katakturuk Formation, Shareza Formation, and Kokarkuyu Formation) (Peryt et al., 1990; Saylor et al., 1998; James et al., 2001; Font et al., 2006; Hoffman et al., 2007; Macdonald et al., 2009a, 2009b). In some instances this interval also contains barite precipitates (e.g., Mackenzie Mountains), which suggests the condensation of substantial amounts of time onto this horizon (Hoffman and Schrag, 2002).

In thinking about the paucity of crystal fan examples in the Phanerozoic it is important to consider another important geobiological process that we do not explicitly address in our model, bioturbation by animals. Bioturbation can strongly affect the carbonate chemistry of the seafloor, by increasing mixing across the sediment-water interface and promoting aerobic respiration and reoxidation reactions (Canfield and Farquhar, 2009). Bioturbation is known from latest Ediacaran time to today, though there are clear secular changes in its intensity recorded by increasing ichnofabric indices (Droser and Bottjer, 1993) and shell bed thickness through time (Kidwell and Brenchley, 1994). These trends probably played at least some role in the relative rarity of crystal fans in Phanerozoic sedimentary successions (Grotzinger and Knoll, 1999). There are also feedbacks between bioturbation and redox processes that may have been important during times of crystal fan reappearance in the record. As seafloor anoxia becomes more prevalent in marine basins, burrowing intensity drops (Canfield, 1989). This will tend to set up strong vertical gradients as less oxygen is mixed into the sediments and more organic carbon is respired via anaerobic metabolisms, increasing $\Omega$ and making conditions for crystal fan precipitation more favorable.

The crystal fans associated with the Permian-Triassic extinction and associated carbon cycle perturbations serve as an informative example of these feedbacks and demonstrate that these sedimentary features could be globally important but related to general changes in the respiration of organic matter on the seafloor due to changing seawater redox budgets, rather than a long-term change in the saturation state of global seawater. The Permo-Triassic extinction was the most devastating mass extinction on record with the loss of $\sim 55 \%$ of marine invertebrate genera (Knoll et al., 1996; Bambach, 2006). Long-lived ecosystems were destroyed and seafloor bioturbation was greatly reduced with only small horizontal traces common (Pruss et al., 2006). Anachronistic carbonate facies are well known from successions of this age (Sepkoski et al., 1991). These include an increase in aragonite cements filling cavities and forming on the seafloor in mid- to late Permian reefs (Mazzullo and Cys, 1979; Grotzinger and Knoll, 1995), and, in many postextinction sections, aragonite crystal fans appear directly on the seafloor or within cavities (Heydari et al., 2003; Pruss et al., 2006; Baud et al., 2007; Payne et al., 2007). Anoxia has been documented from late Permian through Early Triassic ocean basins (Isozaki, 1997; Cao et al., 2009). Various observations imply widespread euxinic conditions, but more importantly, they demonstrate that sulfate reduction was an important process for remineralizing organic matter in anoxic sedimentary environments. In our model framework, these conditions (particularly the increase in anaerobic respiration, mainly through sulfate reduction, and reduction in bioturbation) would have facilitated the genesis of seafloor precipitates and crystal fans.

From the theoretical framework developed above it is clear, at least in principle, that seafloor crystal fans were influenced by geobiological processes operating on the seafloor. Intervals characterized by a higher frequency of crystal fan occurrences could reflect environmental changes global in scope, but perhaps due to other widespread phenomena like first-order changes in the magnitude of primary production and organic matter flux to the seafloor (Logan et al., 1995; Kharecha et al., 2005) and the prevalence of bottom-water anoxia (Wignall, 1994), insofar as these phenomena would have impacted the carbonate chemistry of the sediment-water interface. Given these results, the dynamics of biological activity at the sediment-water interface has the ability to influence modes of carbonate precipitation, and there is the potential for preserving evidence of such phenomena in the rock record.

\section{CONCLUSIONS}

Seafloor crystal fans represent a class of textures and mode of carbonate precipitation that is discrete in time. Substantial interest in these features exists with the goal of understanding their occurrence to help constrain secular changes in the fluid Earth carbon cycle. Our approach here was to build a mathematical framework for the role of microbial metabolism and organic carbon delivery on the sedimentwater interface and to examine the petrography of two specific occurrences. From this work we can draw several conclusions:

1. Fundamental to understanding the petrogenesis of seafloor crystal fan textures is recognition that the nucleation of these features reflects the carbonate chemistry of the sediment-water interface. Geobiological processes involving physical mixing across this horizon (bioturbation) as well as redox reactions involved in the respiration of sedimentary organic carbon during diagenesis and reoxidation of the reduced products play critically important roles by adding or removing DIC and alkalinity, and altering the calcium carbonate saturation state. This is important because it is possible, in principle, that the problem of crystal fan origins can be divorced from surface seawater saturation states.

2. A model of the carbonate chemistry of the sediment-water interface as a function of important geobiological processes reveals two different end-member paths that produce favorable conditions for crystal fan genesis. In one organic matter is remineralized by anaerobic metabolisms that contribute both DIC and alkalinity, buffering or increasing the saturation state of the surface sediments. The second is characterized by little organic input to the sediments, contributing little DIC from respiration, and consequently maintaining favorable chemistry for crystal fan nucleation and growth from the sedimentwater interface. These results suggest the hypothesis, supported by our high-resolution petrographic study of the Beechey and Johnnie formations, that not all crystal fans record the same geobiological phenomena.

3. Crystal fans from the Paleoproterozoic Beechey Formation likely reflect a sedimentary environment favorable for carbonate precipitation due to alkalinity sourced in part from iron reduction, evidenced by their co-occurrence with incipient iron formation and incorporation of high concentrations of reduced metals. Additionally, the sequence stratigraphic context of the Beechey fans suggest that they grew during a condensed interval, with low background sedimentation rates an important condition for growth.

4. Similarly, the crystal fans from the Rainstorm Member of the Neoproterozoic Johnnie Formation are associated with iron-rich detrital sediment, and the trace element composition of the carbonate reflects elevated incorporation of reduced metals in the form of iron and manganese. However, much of the iron and manganese associated with the Rainstorm fans remains in the oxide phase, which points to low delivery of organic matter to the sediment-water interface with little aerobic organic diagenesis to hinder crystal fan precipitation and limited sulfate reduction. The crystal fans from the Rainstorm Member of the Neoproterozoic Johnnie Formation also occur during a maximum flooding interval, suggesting preferential development during maxima in sedimentary accommodation.

\section{ACKNOWLEDGMENTS}

We thank Jena Johnson, Sara Pruss, and an anonymous reviewer for insightful comments. Most analytical work was completed using facilities available in the Division of Geological and Planetary Sciences 
(GPS) at California Institute of Technology with assistance from Chi Ma, George Rossman, and Andrew Matzen. $\mu X R F$ analysis was completed at the Jet Propulsion Laboratory with assistance from Mark Anderson. Support from a Henshaw Fellowship (GPS) and a National Science Foundation Graduate Research Fellowship was provided to K. Bergmann. W. Fischer acknowledges support from the Agouron Institute and a David and Lucile Packard Fellowship for Science and Engineering.

\section{REFERENCES}

Allwood, A.C., Grotzinger, J.P., Knoll, A.H., Burch, I.W., Anderson, M.S., Coleman, M.L., and Kanik, I., 2009, Controls on development and diversity of early Archean stromatolites: Proceedings of the National Academy of Sciences of the United States of America, v. 106, p. 9548-9555, doi: 10.1073/Pnas.0903323106.

ANDERSON, L.A., 1995, On the hydrogen and oxygen content of marine phytoplankton: Deep-Sea Research Part I: Oceanographic Research Papers, v. 42, p. 16751680.

Andres, M.S., Sumner, D.Y., ReID, R.P., and Swart, P.K., 2006, Isotopic fingerprints of microbial respiration in aragonite from Bahamian stromatolites: Geology, v. 34, p. 973-976, doi: 10.1130/G22859a.1.

Babinski, M., Vieira, L.C., and Trindade, R.I.F., 2007, Direct dating of the Sete Lagoas cap carbonate (Bambui Group, Brazil) and implications for the Neoproterozoic glacial events: Terra Nova, v. 19, p. 401-406, doi: 10.1111/ J.1365-3121.2007.00764.X.

BAmbach, R.K., 2006, Phanerozoic biodiversity mass extinctions: Annual Review of Earth and Planetary Sciences, v. 34, p. 127-155, doi: 10.1146/Annurev. Earth.33.092203.122654

Bartley, J.K., and KAH, L.C., 2004, Marine carbon reservoir, C-org-C-carb coupling, and the evolution of the Proterozoic carbon cycle: Geology, v. 32, p. 129-132, doi: 10.1130/G19939.1.

Bartley, J.K., Knoll, A.H., Grotzinger, J.P., and Sergeev, V.N., 2000, Lithification and fabric genesis in precipitated stromatolites and associated peritidal carbonates, Mesoproterozoic Billyakh Group, Siberia, in Grotzinger, J.P., and James, N.P., eds., Carbonate Sedimentation and Diagenesis in the Evolving Precambrian World: Society for Sedimentary Geology (SEPM) Special Publication 67, p. 59-73.

Baud, A., Richoz, S., and Pruss, S., 2007, The Lower Triassic anachronistic carbonate facies in space and time: Global and Planetary Change, v. 55, p. 81-89, doi: 10.1016/J.Gloplacha.2006.06.008.

Bergmann, K.D., Zentmyer, R.A., and Fischer, W.W., 2011, The stratigraphic expression of a large negative carbon isotope excursion from the Ediacaran Johnnie Formation, Death Valley: Precambrian Research, v. 188, p. 45-56.

Beukes, N.J., and KLeIN, C., 1990, Geochemistry and sedimentology of a facies transition-From microbanded to granular iron-formation-In the early Proterozoic Transvaal Supergroup, South Africa: Precambrian Research, v. 47, p. 99-139.

Broecker, W.S., and Takahashi, T., 1966, Calcium carbonate precipitation on Bahama Banks: Journal of Geophysical Research, v. 71, p. 1575-1602.

Broecker, W.S., Langdon, C., and TaKahashi, T., 2001, Factors controlling the rate of $\mathrm{CaCO} 3$ precipitation on Great Bahama Bank: Global Biogeochemical Cycles, v. 15 , p. $589-596$.

Burkhalter, R.M., 1995, Ooidal ironstones and ferruginous microbialites: Origin and relation to sequence stratigraphy (Aalenian and Bajocian, Swiss Jura Mountains): Sedimentology, v. 42, p. 57-74.

Canfield, D.E., 1989, Sulfate reduction and oxic respiration in marine sediments: Implications for organic carbon preservation in euxinic environments: Deep-Sea Research Part a: Oceanographic Research Papers, v. 36, p. 121-138.

Canfield, D.E., and Farquhar, J., 2009, Animal evolution, bioturbation, and the sulfate concentration of the oceans: Proceedings of the National Academy of Sciences of the United States of America, v. 106, p. 8123-8127, doi: 10.1073/ Pnas.0902037106.

Cao, C.Q., Love, G.D., Hays, L.E., Wang, W., Shen, S.Z., and Summons, R.E., 2009, Biogeochemical evidence for euxinic oceans and ecological disturbance presaging the end-Permian mass extinction event: Earth and Planetary Science Letters, v. 281, p. 188-201, doi: 10.1016/J.Eps1.2009.02.012.

Clough, J.G., and Goldhammer, R.K., 2000, Evolution of the Neoproterozoic Katakturuk dolomite ramp complex, northeastern Brooks Range, Alaska, in Grotzinger, J.P., and James, N.P., eds., Carbonate sedimentation and diagenesis in the evolving Precambrian world: Society for Sedimentary Geology (SEPM) Special Publication 67, p. 209-241.

Corsetti, F.A., and Grotzinger, J.P., 2005, Origin and significance of tube structures in Neoproterozoic post-glacial cap carbonates: Example from Noonday Dolomite, Death Valley, United States: PALAIOS, v. 20, p. 348-362, doi: 10.2110/ Palo.2003.P03-96.
Corsetti, F.A., and Kaufman, A.J., 2003, Stratigraphic investigations of carbon isotope anomalies and Neoproterozoic ice ages in Death Valley, California: Geological Society of America Bulletin, v. 115, p. 916-932.

Corsetti, F.A., Lorentz, N.J., and Pruss, S.B., 2004, Formerly-aragonite seafloor fans from Neoproterozoic strata, Death Valley and southeastern Idaho, United States: Implications for "cap carbonate" formation and snowball Earth, in Jenkins, G.S., McMenamin, M.A.S., McKay, C.P., and Sohl, L., eds., The extreme Proterozoic Geology, Geochemistry and Climate, AGU Monograph, v. 146, p. 3344, doi: 10.1029/146GM04.

Droser, M.L., and BotTJer, D.J., 1993, Trends and patterns of Phanerozoic ichnofabrics: Annual Review of Earth and Planetary Sciences, v. 21, p. 205 225.

Dupraz, C., Reid, R.P., Braissant, O., Decho, A.W., Norman, R.S., and Visscher, P.T., 2009, Processes of carbonate precipitation in modern microbial mats: EarthScience Reviews, v. 96, p. 141-162, doi: 10.1016/J.Earscirev.2008.10.005.

Fischer, W.W., and KNoll, A.H., 2009, An iron shuttle for deepwater silica in late Archean and early Paleoproterozoic iron formation: Geological Society of America Bulletin, v. 121, p. 222-235, doi: 10.1130/B26328.1.

Fischer, W.W., Schroeder, S., Lacassie, J.P., Beukes, N.J., Goldberg, T., Strauss, H., Horstmann, U.E., Schrag, D.P., and Knoll, A.H., 2009, Isotopic constraints on the late Archean carbon cycle from the Transvaal Supergroup along the western margin of the Kaapvaal Craton, South Africa: Precambrian Research, v. 169, p. 15-27, doi: 10.1016/J.Precamres.2008.10.010.

Font, E., Nedelec, A., Trindade, R.I.F., Macouin, M., and Charriere, A., 2006, Chemostratigraphy of the Neoproterozoic Mirassol d'Oeste cap dolostones (Mato Grosso, Brazil): An alternative model for Marinoan cap dolostone formation: Earth and Planetary Science Letters, v. 250, p. 89-103, doi: 10.1016/ J.Eps1.2006.06.047.

Fralick, P., and Pufahl, P.K., 2006, Iron formation in neoarchean deltaic successions and the microbially mediated deposition of transgressive systems tracts: Journal of Sedimentary Research, v. 76, p. 1057-1066, doi: 10.2110/ Jsr.2006.095.

Ginsburg, R.N., and James, N.P., 1976, Submarine botryoidal aragonite in Holocene reef limestones, Belize: Geology, v. 4, p. 431-436.

Grammer, G.M., Ginsburg, R.N., Swart, P.K., Mcneill, D.F., Jull, A.J.T., and Prezbindowski, D.R., 1993, Rapid growth rates of syndepositional marine aragonite cements in steep marginal slope deposits, Bahamas and Belize: Journal of Sedimentary Petrology, v. 63, p. 983-989.

Grammer, G.M., Crescini, C.M., McNeill, D.F., and Taylor, L.H., 1999, Quantifying rates of syndepositional marine cementation in deeper platform environments: New insight into a fundamental process: Journal of Sedimentary Research, v. 69, p. 202-207.

Grotzinger, J.P., 1986, Evolution of early Proterozoic passive-margin carbonate platform, Rocknest Formation, Wopmay Orogen, Northwest Territories, Canada: Journal of Sedimentary Petrology, v. 56, p. 831-847.

Grotzinger, J.P., 1989, Facies and evolution of Precambrian carbonate depositional systems: Emergence of the modern platform archetype, in Crevello, P.D., Wilson, J.L., Sarg, J.F., and Read, J.F., eds., Controls on Carbonate Platform and Basin Development: Society for Sedimentary Geology (SEPM) Special Publication 44, p. $79-106$.

Grotzinger, J.P., 1990, Geochemical model for Proterozoic stromatolite decline: American Journal of Science, v. 290A, p. 80-103.

Grotzinger, J.P., 1993, New views of old carbonate sediments: Geotimes, v. 38, p. $12-15$.

Grotzinger, J.P., and Friedman, J.S., 1989, Occurrence of thick crusts of former botryoidal aragonite, Rifle and Beechey Formations (1.97 Ga), Kilohigok Basin, N.W.T: Geological Association of Canada Program with Abstract, v. 14, p. A77.

Grotzinger, J.P., and James, N.P., 2000, Precambrian carbonates: Evolution of understanding, in Grotzinger, J.P., and James, N.P., eds., Carbonate Sedimentation and Diagenesis in the Evolving Precambrian World: Society for Sedimentary Geology (SEPM) Special Publication 67, p. 1-20.

Grotzinger, J.P., and Kasting, J.F., 1993, New constraints on Precambrian ocean composition: Journal of Geology, v. 101, p. 235-243.

Grotzinger, J.P., and Knoll, A.H., 1995, Anomalous carbonate precipitates: Is the precambrian the key to the Permian?: PALAIOS, v. 10, p. 578-596.

Grotzinger, J.P., and Knoll, A.H., 1999, Stromatolites in Precambrian carbonates: Evolutionary mileposts or environmental dipsticks?: Annual Review of Earth and Planetary Sciences, v. 27, p. 313-358.

Grotzinger, J.P., and McCormick, D.S., 1988, Flexure of the early Proterozoic lithosphere and the evolution of Kilohigok Basin (1.9 Ga), Northwest Canadian Shield, in Kleinsphen, K.L., and Paola, C., eds., New Perspectives in Basin Analysis: Springer-Verlag, New York, p. 405-430.

Grotzinger, J.P., and ReAd, J.F., 1983, Evidence for primary aragonite precipitation, lower Proterozoic (1.9 Ga) Rocknest Dolomite, Wopmay Orogen, Northwest Canada: Geology, v. 11, p. 710-713. 
Grotzinger, J.P., Fike, D.A., and Fischer, W.W., 2011, Enigmatic origin of the largest-known carbon isotope excursion in Earth's history: Nature Geoscience, v. 4, p. 285-292, doi: 10.1038/NGEO1138.

Hegenberger, W., 1993, Stratigraphy and sedimentology of the late Precambrian Witvlei and Nama Groups east of Windhoek: Geological Survey of Namibia, Memoir 17, p. 82.

Heydari, E., and Hassanzadeh, J., 2003, Deev Jahi Model of the Permian-Triassic boundary mass extinction: A case for gas hydrates as the main cause of biological crisis on Earth: Sedimentary Geology, v. 163, p. 147-163, doi: 10.1016/ J.Sedgeo.2003.08.002

Heydari, E., Hassanzadeh, J., Wade, W.J., and Ghazi, A.M., 2003, Permian-Triassic boundary interval in the Abadeh section of Iran with implications for mass extinction: Part 1: Sedimentology: Palaeogeography, Palaeoclimatology, Palaeoecology, v. 193, p. 405-423, doi: 10.1016/S0031-0182(03)00258-X.

Higgins, J.A., Fischer, W.W., and Schrag, D.P., 2009, Oxygenation of the ocean and sediments: Consequences for the seafloor carbonate factory: Earth and Planetary Science Letters, v. 284, p. 25-33, doi: 10.1016/J.Epsl.2009.03.039.

Hoffman, P.F., and Schrag, D.P., 2002, The snowball Earth hypothesis: Testing the limits of global change: Terra Nova, v. 14, p. 129-155.

Hoffman, P.F., Kaufman, A.J., Halverson, G.P., and Schrag, D.P., 1998, A Neoproterozoic snowball earth: Science, v. 281, p. 1342-1346.

Hoffman, P.F., Halverson, G.P., Domack, E.W., Husson, J.M., Higgins, J.A., and SchraG, D.P., 2007, Are basal Ediacaran (635 Ma) post-glacial "cap dolostones" diachronous?: Earth and Planetary Science Letters, v. 258, p. 114-131, doi: 10.1016/J.Eps1.2007.03.032.

Hofmann, A., Dirks, P.H.G.M., and Jelsma, H.A., 2004, Shallowing-upward carbonate cycles in the Belingwe Greenstone Belt, Zimbabwe: A record of Archean sea-level oscillations: Journal of Sedimentary Research, v. 74, p. 64-81.

Hofmann, H.J., and JACKSON, G.D., 1987, Proterozoic ministromatolites with radialfibrous fabric: Sedimentology, v. 34, p. 963-971.

Hotinski, R.M., Kump, L.R., and ArThur, M.A., 2004, The effectiveness of the Paleoproterozoic biological pump: A delta $\mathrm{C}-13$ gradient from platform carbonates of the Pethei Group (Great Slave Lake Supergroup, NWT): Geological Society of America Bulletin, v. 116, p. 539-554, doi: 10.1130/B25272.1.

Hu, X.P., and Burdige, D.J., 2007, Enriched stable carbon isotopes in the pore waters of carbonate sediments dominated by seagrasses: Evidence for coupled carbonate dissolution and reprecipitation: Geochimica Et Cosmochimica Acta, v. 71, p. 129-144, doi: 10.1016/J.Gca.2006.08.043

Hu, X.P., and Burdige, D.J., 2008, Shallow marine carbonate dissolution and early diagenesis: Implications from an incubation study: Journal of Marine Research, v. 66, p. $489-527$.

IsozAKI, Y., 1997, Permo-Triassic Boundary superanoxia and stratified superocean: Records from lost deep sea: Science, v. 276, p. 235-238.

James, N.P., Narbonne, G.M., and Kyser, T.K., 2001, Late Neoproterozoic cap carbonates: Mackenzie Mountains, northwestern Canada: Precipitation and global glacial meltdown: Canadian Journal of Earth Sciences, v. 38, p. 1229-1262.

KAH, L.C., and KNOLl, A.H., 1996, Microbenthic distribution of proterozoic tidal flats: Environmental and taphonomic considerations: Geology, v. 24, p. 79-82.

Kaufman, A.J., Corsetti, F.A., and Varni, M.A., 2007, The effect of rising atmospheric oxygen on carbon and sulfur isotope anomalies in the Neoproterozoic Johnnie Formation, Death Valley, USA: Chemical Geology, v. 237, p. 47-63, doi: 10.1016/J.Chemgeo.2006.06.023.

Kennedy, M.J., 1996, Stratigraphy, sedimentology, and isotopic geochemistry of Australian Neoproterozoic postglacial cap dolostones: Deglaciation, delta C-13 excursions, and carbonate precipitation: Journal of Sedimentary Research, v. 66, p. $1050-1064$.

Kharecha, P., Kasting, J., and Siefert, J., 2005, A coupled atmosphere-ecosystem model of the early Archean Earth: Geobiology, v. 3, p. 53-76, doi: 10.1111/J.1472-4669. 2005.00049.X.

Kidwell, S.M., and Brenchley, P.J., 1994, Patterns in bioclastic accumulation through the Phanerozoic: Changes in input or in destruction: Geology, v. 22, p. 1139-1143.

KLeIn, C., and FinK, R.P., 1976, Petrology of Sokoman iron formation in Howells River area, at western edge of Labrador Trough: Economic Geology, v. 71, p. 453 487.

Knoll, A.H., and Fischer, W.W., 2011, Skeletons and ocean chemistry: The long view, in Gattuso, J.P., and Hansson, L., eds., Ocean Acidification: Oxford University Press, New York, p. 67-82.

Knoll, A.H., Bambach, R.K., Canfield, D.E., and Grotzinger, J.P., 1996, Comparative earth history and late Permian mass extinction: Science, v. 273, p. $452-457$.

Ku, T.C.W., Walter, L.M., Coleman, M.L., Blake, R.E., and Martini, A.M., 1999, Coupling between sulfur recycling and syndepositional carbonate dissolution: Evidence from oxygen and sulfur isotope composition of pore water sulfate, South Florida Platform, USA: Geochimica Et Cosmochimica Acta, v. 63, p. 2529-2546.
Kusky, T.P., and Hudleston, P.J., 1999, Growth and demise of an Archean carbonate platform, Steep Rock Lake, Ontario, Canada: Canadian Journal of Earth Sciences, v. 36, p. 565-584.

Logan, G.A., Hayes, J.M., Hieshima, G.B., and Summons, R.E., 1995, Terminal Proterozoic reorganization of biogeochemical cycles: Nature, v. 376, p. 53-56.

Lorentz, N.J., Corsetti, F.A., and Link, P.K., 2004, Seafloor precipitates and Cisotope stratigraphy from the Neoproterozoic Scout Mountain Member of the Pocatello Formation, southeast Idaho: Implications for Neoproterozoic earth system behavior: Precambrian Research, v. 130, p. 57-70, doi: 10.1016/J/ Precamres.2003.10.017.

Macdonald, F.A., Jones, D.S., and Schrag, D.P., 2009a, Stratigraphic and tectonic implications of a newly discovered glacial diamictite-cap carbonate couplet in southwestern Mongolia: Geology, v. 37, p. 123-126, doi: 10.1130/G24797a.1

Macdonald, F.A., McClelland, W.C., Schrag, D.P., and Macdonald, W.P., 2009b, Neoproterozoic glaciation on a carbonate platform margin in Arctic Alaska and the origin of the North Slope subterrane: Geological Society of America Bulletin, v. 121, p. 448-473, doi: 10.1130/B26401.1.

Mazzullo, S.J., and Cys, J.M., 1979, marine aragonite sea-floor growths and cements in Permian phylloid algal mounds, Sacramento Mountains, New Mexico: Journal of Sedimentary Petrology, v. 49, p. 917-936.

Millero, F.J., 2007, The marine inorganic carbon cycle: Chemical Reviews, v. 107, p. 308-341, doi: 10.1021/Cr0503557.

Morse, J.W., Gledhill, D.K., and Millero, F.J., 2003, CaCO3 precipitation kinetics in waters from the Great Bahama Bank: Implications for the relationship between Bank hydrochemistry and whitings: Geochimica Et Cosmochimica Acta, v. 67, p. 2819-2826, doi: 10.1016/S0016-7037(03)00103-0.

Morse, J.W., Arvidson, R.S., and Luttge, A., 2007, Calcium carbonate formation and dissolution: Chemical Reviews, v. 107, p. 342-381, doi: 10.1021/Cr050358j.

Payne, J.L., Lehrmann, D.J., Follett, D., Seibel, M., Kump, L.R., Riccardi, A., Altiner, D., Sano, H., and Wei, J., 2007, Erosional truncation of uppermost Permian shallow-marine carbonates and implications for Permian-Triassic boundary events: Geological Society of America Bulletin, v. 119, p. 771-784, doi: 10.1130/B26091.1.

Peryt, T.M., Hoppe, A., Bechstadt, T., Koster, J., Pierre, C., and Richter, D.K., 1990, Late Proterozoic aragonitic cement crusts, Bambui Group, Minas-Gerais, Brazil: Sedimentology, v. 37, p. 279-286.

Petterson, R., Prave, A.R., Wernicke, B.P., and Fallick, A.E., 2011, The Neoproterozoic Noonday Formation, Death Valley region, California: Geological Society of America Bulletin, v. 123, p. 1317-1336, doi: 10.1130/B30281.1.

Poulton, S.W., Fralick, P.W., and Canfield, D.E., 2004, The transition to a sulphidic ocean similar to 1.84 billion years ago: Nature, v. 431, p. 173-177, doi: 10.1038/Nature02912.

Pruss, S.B., Bottuer, D.J., Corsetti, F.A., and Baud, A., 2006, A global marine sedimentary response to the end-Permian mass extinction: Examples from southern Turkey and the western United States: Earth-Science Reviews, v. 78, p. 193-206, doi: 10.1016/J.Earscirev.2006.05.002.

Pruss, S.B., Corsetti, F.A., and Fischer, W.W., 2008, Seafloor-precipitated carbonate fans in the Neoproterozoic Rainstorm Member, Johnnie Formation, Death Valley Region, USA: Sedimentary Geology, v. 207, p. 34 40, doi: 10.1016/ J.Sedgeo.2008.03.005

Reid, R.P., Visscher, P.T., Decho, A.W., Stolz, J.F., Bebout, B.M., Dupraz, C., Macintyre, L.G., Paerl, H.W., Pinckney, J.L., Prufert-Bebout, L., Steppe, T.F., and Desmarais, D.J., 2000, The role of microbes in accretion, lamination and early lithification of modern marine stromatolites: Nature, v. 406, p. 989-992.

Richter, D.K., Neuser, R.D., Schreuer, J., Gies, H., and Immenhauser, A., 2011, Radiaxial-fibrous calcites: A new look at an old problem: Sedimentary Geology, v. 239 , p. $23-36$.

SAmI, T.T., and James, N.P., 1996, Synsedimentary cements as Paleoproterozoic platform building blocks, Pethei Group, northwestern Canada: Journal of Sedimentary Research, v. 66, p. 209-222.

SANDBERG, P.A., 1985, Aragonite cements and their occurence in ancient limestone, in Schneidermann, N., and Harris, P.M., eds., Carbonate Cements: Society for Sedimentary Geology (SEPM) Special Publication 36, p. 33-57.

Saylor, B.Z., Kaufman, A.J., Grotzinger, J.P., and Urban, F., 1998, A composite reference section for terminal Proterozoic strata of southern Namibia: Journal of Sedimentary Research, v. 68, p. 1223-1235.

SeOng-Joo, L., and Golubic, S., 2000, Biological and mineral components of an ancient stromatolite: Geoyuzhuang Formation, Mesoproterozoic of China, in Grotzinger, J.P., and James, N.P., eds., Carbonate Sedimentation and Diagenesis in the Evolving Precambrian World: Society for Sedimentary Geology (SEPM) Special Publication 67, p. 91-102.

Sepkoski, J.J., Bambach, R.K., and Droser, M.L., 1991, Secular changes in Phanerozoic event bedding and the biological overprint, in Einsele, G., Ricken, W., and Seilacher, A., eds., Cycles and Events in Stratigraphy: Springer-Verlag, Berlin, p. 298-312. 
Simonson, B.M., 1985, Sedimentology of cherts in the early Proterozoic Wishart Formation, Quebec Newfoundland, Canada: Sedimentology, v. 32, p. 23-40.

Simonson, B.M., 1987, Early silica cementation and subsequent diagenesis in arenites from 4 early Proterozoic iron formations of North America: Journal of Sedimentary Petrology, v. 57, p. 494-511.

Simonson, B.M., and Hassler, S.W., 1996, Was the deposition of large precambrian iron formations linked to major marine transgressions?: Journal of Geology, v. 104 , p. $665-676$.

Soetaert, K., Hofmann, A.F., Middelburg, J.J., Meysman, F.J.R., and GreenwOOD, J., 2007, The effect of biogeochemical processes on $\mathrm{pH}$ : Marine Chemistry, v. 105, p. 30-51, doi: 10.1016/J.Marchen.2006.12.012.

Summa, C., 1993, Sedimentologic, stratigraphic, and tectonic controls of a mixed carbonate-siliciclastic succession: Neoproterozoic Johnnie formation, southeast California: Ph.D. thesis, Massachusetts Institute of Technology, Cambridge, Massachusetts, $331 \mathrm{p}$.

Sumner, D.Y., and Grotzinger, J.P., 1993, Numerical modeling of ooid size and the problem of Neoproterozoic giant ooids: Journal of Sedimentary Petrology, v. 63, p. 974-982.

Sumner, D.Y., and Grotzinger, J.P., 1996a, Herringbone calcite: Petrography and environmental significance: Journal of Sedimentary Research, v. 66, p. 419-429.

Sumner, D.Y., and Grotzinger, J.P., 1996b, Were kinetics of Archean calcium carbonate precipitation related to oxygen concentration?: Geology, v. 24, p. 119 122.

Sumner, D.Y., and Grotzinger, J.P., 2000, Late Archean aragonite precipitation: Petrography, facies associations and environmental significance, in Grotzinger, J.P., and James, N.P., eds., Carbonate Sedimentation and Diagenesis in the Evolving Precambrian World: Society for Sedimentary Geology (SEPM) Special Publication 67, p. 123-144.

Sumner, D.Y., and Grotzinger, J.P., 2004, Implications for Neoarchaean ocean chemistry from primary carbonate mineralogy of the Campbellrand-Malmani Platform, South Africa: Sedimentology, v. 51, p. 1273-1299, doi: 10.1111/J.13653091.2004.00670.X.

Verdel, C., Wernicke, B.P., and Bowring, S.A., 2011, The Shuram and subsequent Ediacaran carbon isotope excursions from southwest Laurentia, and implications for environmental stability during the metazoan radiation: Geological Society of America Bulletin, v. 123, p. 1539-1559.
WALKER, J.C.G., 1984, Suboxic diagenesis in banded iron formations: Nature, v. 309, p. $340-342$.

WAlter, L.M., and Burton, E.A., 1990, Dissolution of recent platform carbonate sediments in marine pore fluids: American Journal of Science, v. 290, p. 601-643.

Walter, L.M., Bischof, S.A., Patterson, W.P., and Lyons, T.W., 1993, Dissolution and recrystallization in modern shelf carbonates: Evidence from pore-water and solid-phase chemistry: Philosophical Transactions of the Royal Society of London Series a: Mathematical Physical and Engineering Sciences, v. 344, p. 27-36.

Wignall, P.B., 1994, Black Shales: Oxford University Press, Oxford, 127 p.

Wilson, M.A., and Palmer, T.J., 1992, Hardgrounds and Hardground Faunas: University of Wales, Aberystwyth, Wales, Institute of Earth Studies Publications, v. 9 , p. $1-131$.

Winefield, P.R., 2000, Development of late Paleoproterozoic aragonitic seafloor cements in the McArthur Group, Northern Australia, in Grotzinger, J.P., and James, N.P., eds., Carbonate Sedimentation and Diagenesis in the Evolving Precambrian World: Society for Sedimentary Geology (SEPM) Special Publication 67 , p. $145-159$.

Woods, A.D., and Baud, A., 2008, Anachronistic facies from a drowned Lower Triassic carbonate platform: Lower member of the Alwa Formation (Ba'id Exotic), Oman Mountains: Sedimentary Geology, v. 209, p. 1-14, doi: 10.1016/ J.Sedgeo.2008.06.002.

Woods, A.D., Bottuer, D.J., Mutti, M., and Morrison, J., 1999, Lower Triassic large sea-floor carbonate cements: Their origin and a mechanism for the prolonged biotic recovery from the end-Permian mass extinction: Geology, v. 27, p. 645-648.

Woods, A.D., Bottuer, D.J., and Corsetti, F.A., 2007, Calcium carbonate seafloor precipitates from the outer shelf to slope facies of the Lower Triassic (SmithianSpathian) Union Wash Formation, California, USA: Sedimentology and palaeobiologic significance: Palaeogeography, Palaeoclimatology. Palaeoecology, v. 252, p. 281-290, doi: 10.1016/J.Palaeo.2006.11.053.

Xiao, S.H., Knoll, A.H., Kaufman, A.J., Yin, L.M., and Zhang, Y., 1997, Neoproterozoic fossils in Mesoproterozoic rocks? Chemostratigraphic resolution of a biostratigraphic conundrum from the north China platform: Precambrian Research, v. 84, p. 197-220.

Zeebe, R.E., and Wolf-Gladrow, D.A., 2001, CO2 in Seawater: Equilibrium, Kinetics, Isotopes: Elsevier, Boston, 346 p.

ACCEPTED JANUARY 2, 2013 